\title{
Sociologia do espaço ${ }^{1}$
}

\author{
GEORG SIMMEL
}

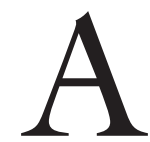

S SEGUINTES investigações constituem um capítulo de uma sociologia que pretendo publicar futuramente, e cuja problematização já formulei anteriormente, neste Anuário (1894). ${ }^{2}$ Espero que elas contribuam para a análise da existência social independentemente do fato de se reconhecer ou rechaçar esse programa como pertinente à sociologia.

Uma das aberrações mais comuns do impulso causal humano consiste em assumir condições formais, sem as quais certos acontecimentos não podem ocorrer, como causas positivas, produtivas desses mesmos acontecimentos. $\mathrm{O}$ exemplo típico é o poder do tempo - uma figura idiomática que inúmeras vezes nos engana, levando-nos a não buscar as reais causas do abrandamento ou arrefecimento das concepções, de processos anímicos de cura ou de hábitos cristalizados. Em vários casos, não será diferente com o significado do espaço. Se uma teoria estética proclama que a função essencial das artes plásticas é fazer-nos sentir o espaço, ela não atenta para o fato de que o nosso interesse se centra exclusivamente nas figurações ${ }^{3}$ especiais das coisas, e não no espaço ou na espacialidade em geral, que apenas constituem a conditio sine qua non de tais figurações, sem contudo perfazerem a essência particular dessas mesmas coisas ou serem seu fator gerador. Se uma interpretação da história destaca o fator ${ }^{4}$ do espaço de maneira a compreender a grandeza ou pequeneza dos impérios, a condensação ou dispersão das populações, a mobilidade ou estabilidade das massas etc. como forças de toda a vida histórica como que irradiantes do espaço, então também aqui o necessário envolvimento espacial de todas essas constelações corre o risco de ser confundido com as suas causas positivamente efetivas. Evidentemente, impérios não podem possuir qualquer perímetro, seres humanos não podem estar próximos ou distantes uns dos outros sem que o espaço ofereça sua forma para tal, do mesmo modo como os processos atribuídos ao poder do tempo não podem transcorrer fora do tempo. No entanto, os conteúdos dessas formas experienciam a particularidade de seus destinos apenas através de outros conteúdos; o espaço permanece sempre a forma em si mesma sem efeitos, em cujas modificações as energias reais de fato se revelam, porém apenas de maneira análoga a como a língua exprime processos de pensamento que evidentemente transcorrem em, mas não através de, palavras. Um perímetro geográfico de umas tantas milhas quadradas não forma um grande império; quem o faz são as forças psicológicas que mantêm os habitantes de tal região politicamente coesos a partir de um ponto central dominante. Não é a forma da proximidade ou distância espacial que gera os fenômenos especiais da vizinhança ou da estranheza, 
por mais incontestável que isso possa parecer. Muito pelo contrário: também esses são fatos gerados puramente por conteúdos anímicos, e seu desenrolar se relaciona com sua forma espacial de modo em princípio análogo ao de uma batalha ou conversa telefônica com suas formas espaciais - embora seja indubitável que também esses processos só tenham como se realizar em condições espaciais bem específicas. É no requisito de funções especificamente anímicas para cada uma das figurações históricas do espaço que se espelha o fato de que o espaço em geral é apenas uma atividade da alma, apenas a maneira humana de unir estímulos sensoriais em si desconexos em visões unitárias.

Apesar desse estado de coisas, a ênfase nos significados espaciais das coisas e processos não é injustificada. Pois tais coisas e processos de fato frequentemente transcorrem de um modo tal, que a condição formal ou negativa de sua espacialidade se destaca particularmente para a observação, e que essa espacialidade constitui, para nós, a documentação mais clara das forças reais. Embora um processo químico ou uma partida de xadrez se vincule, afinal, tanto a condicionamentos espaciais como uma expedição militar ou o escoamento de produtos agrícolas, a direção do olhar que o interesse epistêmico toma, em um ou outro caso, é tão distinta, em termos metodológicos, que, no primeiro deles, a questão das condições e determinações de espaço e lugar se coloca completamente fora da perspectiva do olhar, enquanto, no segundo caso, ela decididamente ali se inclui. Em certo ponto, Kant definiu o espaço como a possibilidade de se estar junto. ${ }^{5}$ Nos diversos modos da interação dos indivíduos, a sociação ${ }^{6}$ gerou outras possibilidades de se estar junto - no sentido espiritual. ${ }^{7}$ Contudo, algumas dessas possibilidades de se estar junto se realizam de um modo tal que a forma espacial na qual isso ocorre, como em geral em todos os casos, justifica uma ênfase especial, para nossos fins epistêmicos. Assim, no interesse de perscrutar as formas de sociação, inquirimos o significado que as condições espaciais de uma sociação possuem, em perspectiva sociológica, para a sua determinação e desenvolvimentos restantes.

I. Primeiramente, existem algumas qualidades fundamentais da forma espacial com as quais as figurações da vida comunitária con$\operatorname{tam}^{8}$

A. Integra tais atributos algo que se pode denominar a exclusividade do espaço. Do mesmo modo que só há um único espaço geral do qual todos os espaços individuais são pedaços, toda parte espacial possui uma espécie de singularidade para a qual quase não existe analogia. Pensar no plural uma parte espacial localizada de maneira determinada é um completo contrassenso. E é precisamente isso que permite ser possível existirem ao mesmo tempo exemplares completamente idênticos de uma pluralidade de outros objetos; pois somente devido ao fato de que cada um ocupa uma outra parte espacial, e essas não podem jamais coincidir, é que se trata de várias, embora sua composição seja absolutamente unitária. Essa unicidade do espaço, portanto, se comunica aos 
objetos na medida em que esses são representados como elementos que preenchem o espaço. E isso se torna especialmente importante para a prática em relação aos objetos dos quais nós costumamos justamente ressaltar e usar em particular o significado espacial. Isso ocorre sobretudo em relação ao chão e à terra, que constituem a condição para que a tridimensionalidade do espaço seja preenchida e frutifique, para os nossos propósitos. Na medida em que uma formação ${ }^{9}$ social está fundida ou, por assim dizer, solidária com determinada extensão de terra, ela possui um caráter de unicidade ou exclusividade que, de outro modo, não seria atingível da mesma forma. Certos tipos de associação só conseguem realizar sua forma sociológica integral da seguinte maneira: dentro da zona espacial que preenche uma das configurações de tais tipos de associação, não há lugar para uma segunda configuração. Em compensação, de outras associações é possível que um número qualquer - sociologicamente da mesma espécie - preencha o mesmo perímetro, sendo elas reciprocamente como que permeáveis; já que elas não possuem nenhuma relação interna com o espaço, também não podem entrar em colisões espaciais. Para o primeiro caso, o único exemplo plenamente correspondente é o Estado. Dele se chegou a dizer que não seria uma agremiação entre muitas, mas a agremiação que a tudo domina, portanto única em sua espécie. Essa representação, cuja pertinência para a totalidade do Estado não está em questão aqui, vale, em todo caso, por referência ao caráter espacial do Estado. A espécie de associação entre os indivíduos que o Estado gera, ou que o gera, está de tal modo vinculada ao território que um segundo Estado ali é inconcebível. Em certa medida, a comuna ${ }^{10}$ possui o mesmo caráter: dentro dos limites de uma cidade só pode de fato haver essa cidade; e se, por acaso, efetivamente surgir uma segunda nesses mesmos limites, então não são duas cidades no mesmo chão e na mesma terra, mas em dois territórios outrora de fato unidos, porém agora separados. No entanto, essa exclusividade não é tão absoluta como aquela do Estado. A zona de significado e efetividade de uma cidade - no interior de um Estado - não termina, afinal, em sua fronteira geográfica, mas se estende de modo mais ou menos perceptível, em ondas espirituais, econômicas, políticas, pelo território todo, à medida que a administração geral do Estado faz as forças e interesses de cada parte se amalgamarem com aquelas do todo. Desse ponto de vista, a comunidade ${ }^{11}$ perde o seu caráter exclusivo e se expande funcionalmente pela totalidade do Estado, de tal modo que esse constitui a zona comum de influência para as extensões por assim dizer ideais de todas as comunidades particulares. Como cada uma dessas ultrapassa suas fronteiras imediatas, ela depara com todas as outras que são efetivas na mesma totalidade da região, de modo que ali nenhuma comunidade é única, e cada uma tem sedimentada em torno da exclusividade de sua região mais estrita uma segunda, na qual ela não é a única. Também dentro da respectiva cidade essa forma local da vida grupal pode se repetir. Quando, a partir das comunidades de comarca alemãs, se desenvolveram cidades episcopais, a comunidade livre nunca foi proprietária da comarca urbana inteira; antes, existia a seu lado um bispo que 
tinha por trás de si uma agremiação de domínio de gente dependente, regida por direito próprio. Além disso, na maioria das cidades havia ainda uma propriedade feudal do rei com uma comunidade camponesa especialmente administra$\mathrm{da}$, e, finalmente, ainda mosteiros e comunidades judaicas independentes que viviam em regime de direito próprio. Portanto, em tempos mais remotos havia, sem dúvida, comunidades dentro das cidades, mas não havia comunidades urbanas propriamente ditas. Inevitavelmente, entretanto, se desenvolveram, a partir da contiguidade, efeitos interativos que, antes da fusão de todas essas entidades separadas em um organismo citadino, encontraram expressão primeiramente em uma paz citadina comum. Por meio dessa paz, oferecia-se a todos os habitantes um direito protetor comum acima de seus direitos pessoais especiais. Ou seja, a esfera jurídica de cada distrito ultrapassava a sua demarcação, no interior da qual cada comunidade era única: ela estendia-se, de um modo para todos uniforme, por sobre uma região total que incluía a todos, perdendo, com tal ampliação de sua essência efetiva, a exclusividade local. Esse tipo constitui a transição para o próximo estágio da relação espacial de grupos, no qual estes, por não estarem limitados a uma extensão determinada, tampouco possuem o direito à unicidade no interior de tal extensão. Assim foi possível que, no território de uma cidade, coexistissem tantas quantas fossem as corporações profissionais com idêntica constituição sociológica. Pois cada uma era, de fato, a corporação da cidade inteira: elas não compartilhavam a extensão dada em termos qualitativos, mas funcionalmente; não se chocavam no espaço porque, como formações sociológicas, não se definiam espacialmente, mas sim em termos de lugar. Em relação a seu conteúdo, elas possuíam a exclusividade de preencher a extensão espacial, na medida em que, para cada ofício específico, existia justamente uma só corporação na cidade, e não havia espaço para uma segunda. Em relação à sua forma, inúmeras formações dessa espécie podiam preencher sem contradições o mesmo espaço. O polo mais extremo dessa sequência é exemplificado pela Igreja, ao menos quando ela, como no caso da Igreja católica, reclama para si oniextensão e liberdade em relação a qualquer barreira local. Não obstante, várias religiões dessa espécie podiam encontrar-se juntas na mesma cidade, por exemplo. A comunidade católica não seria menos "a comunidade católica da cidade" - isto é, mantendo-se numa determinada relação organizacional-local com a cidade como unidade -, do mesmo modo como a comunidade de qualquer outra religião. O princípio da Igreja é não espacial, e por isso, embora estendendo-se por sobre qualquer espaço, ela não exclui de nenhum deles uma formação analogamente formada. Há, dentro do espacial, um paralelo em relação à oposição temporal entre o eterno e o atemporal: este último, por sua essência, não é de modo algum tangenciado pela questão do agora ou do antes ou depois; portanto, ele se encontra acessível ou presente em qualquer momento temporal. Já o eterno encerra precisamente uma noção de tempo, a saber, de tempo infinito e ininterrupto. A diferença análoga no espacial, e para a qual não possuímos termos simples, se constitui, por um lado, das formações supraespaciais que, por seu 
sentido interno, não possuem relação nenhuma com o espaço, mas que, precisamente por isso, nutrem uma relação uniforme com cada ponto desse mesmo espaço. Por outro lado, tal diferença se constitui das formações que desfrutam de uma relação uniforme e constante com todos os pontos espaciais em termos de uma solidariedade com o espaço que é real e fundamental em qualquer parte; e não como uma indiferença uniforme e constante - isto é, no fundo, como mera possibilidade. O tipo mais puro da primeira formação é visivelmente a Igreja; o da última, o Estado, e entre ambos se intercalam fenômenos intermediários dos quais já apontei alguns. Assim, talvez seja possível lançar uma luz especial sobre a essência formal de formações sociais variegadas, a partir de seu grau na escala que vai da fixação territorial total [, e da exclusividade daí resultante, à supraespacialidade completa ${ }^{12}$ ] e à possibilidade resultante [dessa última], de um condomínio de várias formações da mesma espécie por sobre o mesmo segmento espacial. Por essa razão, a proximidade ou a distância, a exclusividade ou a multiplicidade que a relação do grupo apresenta em relação a seu chão e sua terra, muitas vezes são a raiz e o símbolo da estrutura desse mesmo grupo.

B. Outra qualidade do espaço que opera de modo crucial sobre as interações sociais reside no fato de que o espaço se decompõe, para o nosso aproveitamento prático, em pedaços que valem como unidades e - como causa e como efeito disso - são emoldurados por limites. Quer as configurações da superfície terrestre pareçam nos esboçar a moldura que inscrevemos na ausência de limites do espaço, quer linhas puramente ideais separem pedaços congêneres de solo como um divisor de águas para aquém e além dos quais cada pedacinho gravita em direção a outro centro: sempre percebemos o espaço que um grupo social preenche em algum sentido, como uma unidade que tanto quanto exprime e sustenta a unidade desse grupo é por ela sustentado. A moldura, limite definido de uma formação por retroceder sobre si mesma, possui para o grupo social um significado muito semelhante àquele que tem para uma obra de arte. Nesta, a moldura exerce as duas funções que, na verdade, apenas são dois lados de uma só: isolar a obra de arte do mundo circundante e encerrá-la em si mesma. A moldura anuncia que em seu interior se encontra um mundo sujeito apenas às suas próprias normas, não envolvido nas determinações e movimentos do mundo circundante. Ao simbolizar a unidade autossuficiente da obra de arte, a moldura reforça simultaneamente por si própria a realidade e a impressão dessa mesma unidade. Assim, pelo fato de seu espaço existencial estar cercado por limites nitidamente conscientes, uma sociedade se caracteriza como internamente coesa, e vice-versa: a unidade interativa, a relação funcional de cada elemento com qualquer outro, ganha a sua expressão espacial no limite que a emoldura. Talvez não haja nada que evidencie tão bem a força em particular da coesão estatal como o fato de que essa centripetalidade sociológica, essa coerência afinal apenas anímica de personalidades, se eleva a uma imagem como que sensorialmente sentida de uma linha limítrofe firmemente circundante. Raras vezes se reconhece quão 
maravilhosamente a extensibilidade do espaço vai aqui ao encontro da intensidade das relações sociológicas; quanto a continuidade do espaço, precisamente por, em termos objetivos, não conter em parte alguma um limite absoluto, justamente por isso permite traçá-la em termos subjetivos onde quer que seja. Em relação à natureza, qualquer fixação de limite é uma arbitrariedade, inclusive no caso de uma situação insular, já que, em princípio, também é possível "tomar posse" do mar. Precisamente devido a essa indeterminação prévia por parte do espaço natural, a precisão incondicional que, não obstante, caracteriza o limite físico estabelecido em determinado momento, ilustra particularmente bem o poder formador do nexo social e a necessidade internamente motivada desse poder. Daí que a consciência mais intensa de se estar cercado por limites talvez não se dê em relação às assim chamadas fronteiras naturais (montanhas, rios, mares, ermos), mas precisamente em relação a fronteiras políticas, que apenas estabelecem uma linha geométrica entre dois vizinhos. E isso, precisamente porque aqui deslocamentos, ampliações, contrações, fusões estão muito mais próximos; porque a formação, na sua extremidade, vai de encontro a limites vivos, animicamente efetivos, dos quais não apenas partem resistências passivas, mas repulsões bem ativas. Qualquer fronteira dessa espécie significa defensiva e ofensiva. Ou talvez, mais corretamente: ela é a expressão espacial daquela relação unitária entre dois vizinhos para a qual não contamos com nenhuma expressão unitária, e que podemos, por exemplo, designar como estado de indiferença de defensiva e ofensiva, como estado de tensão no qual ambas repousam em latência, podendo essa relação se desenvolver ou não.

Evidentemente, isso não significa negar que o estabelecimento psicológico de limites encontre facilitação e realce naqueles encerramentos naturais das regiões; e mais, devido à estruturação de sua área básica, o espaço frequentemente adquire divisões que matizam de modo singular as relações dos habitantes entre si e com aqueles que se encontram fora. O exemplo mais conhecido são os habitantes das montanhas, com a sua unidade peculiar de senso libertário e conservadorismo, de aspereza do comportamento recíproco e apego passional ao solo, embora isso gere um vínculo extraordinariamente forte entre eles. O conservadorismo nos vales serranos se explica com bastante facilidade a partir da dificuldade de transações ${ }^{13}$ com o mundo exterior e a consequente falta de estímulos à mudança; lá onde a situação serrana não exerce esse efeito proibitivo, como em algumas paisagens gregas, a tendência conservadora não prevalece de modo algum. Portanto, ela apenas tem motivação negativa em oposição, por exemplo, a outras determinações geográficas com o mesmo resultado: o Nilo oferece a seus ribeirinhos, por um lado, uma extraordinária constância daquilo que ele lhes proporciona, e da atividade requerida para tal aproveitamento. Por outro lado, é tamanha a fertilidade de seu vale que a população uma vez ali assentada não encontra motivação para movimentos inquietos. Esses fundamentos muito positivos imprimem nessa região uma uniformidade de conteúdos sempre recorrentes de vida, prendem-na como que à regularidade de uma máquina, e 
frequentemente impuseram ao vale do Nilo um enrijecimento conservador por séculos; enrijecimento que já por razões geográficas não era mais alcançável na costa do Mar Egeu.

A noção de limite é extremamente importante em todas as relações de seres humanos entre si, ainda que o seu sentido não seja sempre sociológico; porque, bem frequentemente, ele indica apenas que a esfera de uma personalidade encontrou um limite conforme o poder ou a inteligência, conforme a capacidade de suportar ou de desfrutar - mas sem que a essa extremidade se juntasse então a esfera de outro, estabelecendo, com o próprio limite, o limite da primeira de modo mais perceptível. Este último caso, o limite sociológico, envolve uma interação bem peculiar. Cada um dos dois elementos exerce efeitos sobre o outro ao estabelecer-lhe o limite, mas o conteúdo desse efeito é justamente a determinação de $n \tilde{a} o$ querer ou não poder operar para além desse limite; ou seja, sobre o outro. Se essa noção geral da limitação recíproca deriva do limite espacial, já numa análise mais profunda esse último é apenas a cristalização ou espacialização dos processos limitadores anímicos, os únicos de fato reais. Não são os países nem os terrenos, nem o distrito urbano nem o rural que se delimitam reciprocamente; mas os habitantes ou proprietários exercem o efeito recíproco que acabo de apontar. Das esferas de duas personalidades ou complexos de personalidades, cada uma ganha uma coerência interna para si, um referenciamento recíproco dos seus elementos, uma relação dinâmica para com o seu centro. E é precisamente por isso que se estabelece entre os dois aquilo que se simboliza no limite espacial: a complementação da medida positiva do poder e do direito da própria esfera, através da consciência de que o poder e o direito justamente não se expandem para dentro da outra esfera. O limite não é um fato espacial com efeitos sociológicos, mas um fato sociológico que assume sua forma espacialmente. O princípio idealista de que o espaço é a nossa representação - ou melhor: de que ele se origina de nossa atividade sintética, através da qual damos forma ao material sensitivo - se especializa aqui de tal modo que a figuração espacial que denominamos limite é uma função sociológica. Evidentemente, uma vez que o limite tenha se tornado uma formação espacial-sensorial que inscrevemos na natureza, independentemente de seu sentido sociológico-prático, isso exerce um forte efeito retroativo sobre a consciência da relação entre as partes. Enquanto essa linha apenas marca a diversidade de ambas as relações - entre os elementos no interior de uma esfera, e entre tais elementos e os de outra -, ela se torna uma energia viva que, em cada esfera, preme uns contra os outros e não os deixa sair de sua unidade, e que se intercala entre ambos como uma força física que irradia repulsões para ambos os lados. Talvez seja na pluralidade de todas as relações entre indivíduos assim como entre grupos, que a noção de limite se torne de algum modo importante. Onde quer que os interesses de dois elementos se voltem para um mesmo objeto, a possibilidade de sua coexistência depende de que uma linha limítrofe no interior do objeto divida as esferas de tais interesses - quer essa linha seja, como limite de direito, 
o término da disputa, quer, como limite de poder, o seu início. Apenas relembro um caso incomensuravelmente significativo para toda e qualquer existência social humana. Toda convivência mais estreita se baseia invariavelmente no fato de que, por meio de hipóteses psicológicas, cada um sabe mais do outro do que este lhe mostra de modo imediato e com vontade consciente. Porque, se dependêssemos apenas do revelado, somente teríamos diante de nós a cada vez alguns fragmentos acidentais e descontextualizados de uma alma, ao invés de um ser humano unitário que compreendemos e com o qual podemos contar. Portanto, temos de complementar os fragmentos dados através de ilações, de interpretações e interpolações, até que emerja um ser humano tão completo como o necessitamos internamente, e para a prática da vida. No entanto, a esse indubitável direito social à penetração no outro, quer este queira ou não, se opõe a propriedade privada que esse tem sobre seu ser anímico, o seu direito à discrição; pois, afinal, discrição não significa apenas não abrir cartas alheias e não escutar atrás da porta, mas também abster-se de matutações e associações através das quais seria possível penetrar, contra a vontade do outro, em suas intimidades e verdades inconfessáveis. Onde, porém, se situa o limite entre a construção permitida, inclusive indispensável, da alma alheia e essa indiscrição psicológica? E, afinal, esse precário limite factual só significa o limite entre as duas esferas de personalidade, significa que a consciência de alguém somente pode recobrir a esfera do outro até certa linha, e que a partir dessa começa invulneravelmente a esfera do outro, sobre cuja revelação cabe unicamente a ele sozinho dispor. É evidente que a condução infinitamente variável dessa linha mantém uma estreita interação com a estrutura toda da vida social: em tempos primitivo-indiferenciados, o direito a essas ampliações de limites psicológicos se torna maior, mas o interesse por elas talvez seja menor do que em tempos de seres humanos muito individualizados e de relações complicadas; em negociações comerciais, esse limite se demarcará diferentemente do que na relação entre pais e filhos; entre diplomatas ele será diverso do que entre ex-companheiros de guerra. Nesse problema aparentemente insignificante e, não obstante, extremamente importante para a análise mais profunda da existência social, revela-se bem o quanto definições de limites dessa espécie exprimem a totalidade das relações interativas entre indivíduos; quanta variedade absolutamente não fixável de delimitações, e, sobretudo, quanto fluir e deslocar constantes as dominam. Precisamente por isso toquei aqui nesse assunto bem distante do problema espacial, para evidenciar, com base nele, a solidez e a visibilidade incomparáveis que os processos de delimitação social adquirem através de sua espacialização. Cada limite é um acontecimento anímico, mais especificamente: sociológico. Mas, ao aplicar-se em uma linha no espaço, a relação de reciprocidade ganha uma clareza e segurança, em relação a seus lados positivos e negativos - muitas vezes, obviamente, também uma rigidez -, que the costumam ser negadas enquanto o encontro e a divisão das forças e direitos ainda não estão projetados numa figuração sensorial, permanecendo por isso sempre, por assim dizer, no status nascens. 
Como se tratou aqui, portanto, essencialmente das interações que se desenrolam entre o aquém e o além do limite, também carecem de ao menos um exemplo as interações que o limite gera como moldura entre os elementos em seu interior. $\mathrm{O}$ essencial é aqui a estreiteza ou a amplitude da moldura - embora de modo algum o unicamente essencial. Porque também a forma na qual a moldura espacial insere o grupo, sua energia homogênea ou com força coesiva diversa em distintos pontos, a questão de se a moldura é produzida, em toda parte, pela mesma formação (como, por um lado, no caso de ilhas, por outro, no caso de estados na situação de San Marino ou dos estados tributários indianos), ou se é composta de várias formações vizinhas: tudo isso é de significado indubitável para a estrutura interna do grupo, mesmo que aqui apenas se aluda a tal significado. Ora, a estreiteza e amplitude da moldura de modo algum coincidem sempre com a pequeneza ou grandeza do grupo. Antes, importam as forças de tensão que se desenvolvem no interior do grupo; quando essas encontram espaço suficiente sem, em sua expansão, se chocar com os limites, então a moldura é justamente ampla, mesmo que se congreguem em seu interior relativamente muitas pessoas, tal como muitas vezes é o caso da constelação de impérios orientais. Por outro lado, a moldura é estreita quando ela, mesmo com um número restrito de pessoas, opera como uma amarração que certas energias, não passíveis de se desenvolverem para dentro, procuram constantemente ultrapassar. Veneza, por exemplo, experimentou de maneira evidente o efeito dessa última constelação sobre a forma social: a constrição de seu território, estrita e de modo algum passível de ser rompida imediatamente, a compeliu mais à expansão por assim dizer dinâmica, nas grandes relações mundiais, do que a uma ampliação territorial do poder; a qual, por sua vez, numa situação dessas oferece apenas chances restritas. Tal política, espacialmente de largo alcance, ultrapassando aquilo que se situa perto, exige, porém, consideráveis requisitos intelectuais, que a grande massa não consegue realizar. Por isso, a democracia direta esteve fora de cogitação para Veneza. Em conformidade com as suas condições espaciais de vida, ela teve que cultivar uma aristocracia que, como se chegou a dizer, mandava no povo como os oficiais de um navio na tripulação.

Como fato formal-sociológico, a moldura espacial do grupo de modo algum se restringe à circunscrição política. A sua estreiteza ou amplitude exerce as suas consequências conformadoras, com as respectivas modificações, onde quer que um número de pessoas se ajunte socialmente. O caráter, frequentemente ressaltado, da multidão reunida - sua impulsividade, seu entusiasmo, sua facilidade para o arrebatamento - se deve com certeza em parte também ao fato de que ou ela se encontra ao ar livre ou, ao menos, em uma localidade muito grande - em comparação com outros espaços de permanência. $O$ grande espaço ao ar livre dá ao ser humano um sentimento de liberdade de movimento, de poder alcançar o indefinido, de estabelecer de modo indefinido metas amplas - algo que em quartos estreitos fica decisivamente dificultado, em termos sensoriais. O fato, contudo, de que muitas vezes tais espaços são por demais estreitos em 
termos relativos - ou seja, de que estão superlotados -, só consegue multiplicar esse efeito psíquico, o crescimento do impulso psíquico individual para além de seus limites habituais. Pois ele deve aumentar aquele sentimento de coletividade que funde cada indivíduo numa unidade para além de sua individualidade; que o arrebata, como que por uma maré de tempestade, para além de suas diretivas e responsabilidades pessoais. Os efeitos sugestivos excitantes de uma grande massa e de suas manifestações anímicas totais, em cuja forma o indivíduo não reconhece a sua contribuição, aumentam na medida de sua compressão física, e tanto mais consideravelmente quanto maior for o espaço que ela ocupa. Uma localidade que oferece, por cima de uma densa aglomeração de gente, um espaço aéreo insolitamente grande a cada um, deve favorecer aquele sentimento de expansão e desdobramento de força em direção ao indefinido; indefinido este para o qual as grandes massas reunidas se dispõem com tanta facilidade, e que, num quarto estreito habitual cuja moldura o olhar pode abarcar com clareza, só aparece ocasionalmente para indivíduos excepcionais. Essa indefinição da moldura espacial, que tão vivamente apóia as excitações coletivas típicas - como, em geral, a vagueza e a amplidão dos limites operam em termos de excitação, de sedução, de redução de uma clara consciência também no sentido não espacial -; justamente essa indefinição torna também as aglomerações no escuro tão perigosas que, nas cidades medievais, a polícia muitas vezes procurou impedi-las interditando becos à noite com correntes etc. A escuridão oferece à reunião em geral uma moldura toda especial, que conduz a significação do estreito e do amplo a uma união peculiar. É que, ao abarcar com a vista apenas o entorno mais próximo, erguendo-se por trás desse uma parede negra impenetrável, a pessoa se sente estreitamente apertada com os mais próximos; a delimitação em relação ao espaço para além do perímetro visível atingiu o seu caso-limite: esse espaço parece ter absolutamente sumido. Por outro lado, precisamente isso faz desaparecer também os limites realmente existentes, a fantasia expande o escuro a possibilidades exageradas, a pessoa se sente rodeada por um espaço fantástico-indefinido e irrestrito. À medida que a ansiedade e insegurança naturais no escuro são combatidas por meio da compressão física estrita e da interdependência mútua de muitos, geram-se aquelas excitação e incalculabilidade temidas que são próprias da confluência no escuro, no modo de uma intensificação e combinação muito singulares da delimitação espacial inclusiva e daquela expansiva.

C. A terceira significação do espaço para as figurações sociais reside na $f$ $x a c ̧ \tilde{a} o$ que ele possibilita a seus conteúdos. O fato de um grupo ou determinados elementos individuais desse grupo ou objetos essenciais de seu interesse estarem totalmente fixados ou serem indetermináveis, em relação ao espaço: isso deve influenciar visivelmente a sua estrutura. E o quanto as constituições de grupos nômades ou assentados são determinadas, em suas diferenças, por tal fato, já foi suficientemente tratado para requerer aqui mais do que uma alusão. De modo algum se trata somente de uma continuidade esquemática do princípio de fixação: que, valendo no espacial, tal princípio se revelaria como estabilização e 
ordenamento sólido agora também nos conteúdos objetivos da vida. Porque esse nexo facilmente compreensivo não vale nem mesmo de modo contínuo; precisamente em condições muito consolidadas, distantes da possibilidade de desenraizamento externo, é possível prescindir de certas regulações e controles legais que são urgentemente necessários em ocasiões de insegurança geral e em circunstâncias agitadas, mais facilmente expostas à fragmentação.

Uma significação sociológica mais especial da fixação no espaço pode ser designada pelo termo simbólico de "ponto de rotação": a fixidez espacial de um objeto de interesse provoca determinadas formas de relação que se agrupam em torno dele. Ora, qualquer bem imóvel em torno do qual se realizam negociações, transações econômicas de qualquer espécie, é, na verdade, um tal ponto de rotação estável com condições e interações lábeis. Contudo, ao menos hoje a imobilidade espacial do objeto não determina essas condições de um modo sociologicamente muito característico. Isso pode ser observado, numa variação não desinteressante, na relação entre indivíduos economicamente ativos que se realiza na hipoteca. Ao motivo que precisamente faz que essa se vincule quase que com exclusividade à propriedade imóvel juntam-se a fixidez dessa última e sua indestrutibilidade, a qual pode ser considerada o correlato da exclusividade anteriormente abordada: pela unicidade à qual cada parte de nosso espaço fica, por assim dizer, restrita, ele ganha a eternidade em virtude da qual o terreno é tão especialmente apropriado para o empenho hipotecário. Porque só assim é possível que o objeto do empenho permaneça nas mãos do devedor e, não obstante, esteja completamente garantido ao credor; ele nem pode ser levado embora nem confundido com outro. No entanto, acontece que o princípio do seguro tornou acessíveis à hipoteca precisamente tais objetos que carecem absolutamente da fixação no espaço: a saber, os navios. Porque aquilo que é especialmente importante na fixação espacial para a hipoteca - a aptidão para $o$ cadastramento público -, isso nos navios se atinge facilmente de outra maneira. Com isso, a especificidade substantiva se revelou, como em muitos outros casos, como sendo na verdade uma determinação funcional. A fixidez, que favorecia como qualidade invariável do terreno a hipoteca, na realidade atinge isso ao menos em parte através da notoriedade pública a que ela dispõe; notoriedade pública esta que, contudo, também pode ser produzida com igual sucesso por outros meios. Assim, portanto, é verdade que o ponto de rotação da interação econômica é aqui um valor sobretudo fixado espacialmente; porém, no fundo, não devido à sua imobilidade, mas devido a certas funções vinculadas a essa. Diferente foi, contudo, na Idade Média, que, de qualquer modo, exigiu uma mistura totalmente distinta de estabilidade e mobilidade dos conteúdos da vida. Encontramos nas transações medievais inúmeras "relações" que, para a nossa compreensão presente, escapam completamente à ação econômica e de direito privado, mas que foram transformadas em objetos de tal ação. $\mathrm{O}$ poder de dominação sobre os territórios, assim como a sua jurisdição - padroados da Igreja assim como direitos fiscais, caminhos assim como privilégios de cunhar moedas: 
tudo isso é vendido ou emprestado, dado em penhor ou como presente. Transformar outra vez objetos tão lábeis, que já em si consistem em meras interações entre pessoas, em objetos de interações econômicas, teria levado em maior grau ainda a estados instáveis e precários, se todos esses direitos e relações não tivessem tido a peculiaridade de estarem indistanciavelmente fixados no lugar de seu exercício. Esse foi o fator de estabilidade que conferiu tanta solidez à sua essência puramente dinâmica e relativista, que justamente em torno deles se tornou, então, possível o agrupamento de outras interações econômicas. A sua fixação local não era como aquela de um objeto substantivo que fosse reencontrado sempre no mesmo ponto, mas como aquela, na realidade, ideal de um ponto de rotação que mantém um sistema de elementos a uma distância e em interação determinada, em interdependência recíproca.

É sempre lá onde o contato ou a junção de elementos de resto independentes só pode ocorrer em um local determinado, que a localidade fixada adquire significado como ponto de rotação de relações sociológicas. Abordo alguns exemplos desse fenômeno, que, na verdade, representa uma interação entre a determinação sociológica interna e aquela espacial. Para igrejas na diáspora, é uma política extremamente inteligente instalar logo uma capela e um posto de assistência espiritual onde quer que viva um número mínimo de seguidores, dentro de um distrito. Essa fixação espacial se torna um ponto de rotação para as relações e a coesão dos fiéis, de modo que não se desenvolvem apenas forças comunitárias religiosas, ao invés de meras forças isoladas; mas as forças que irradiam de tal centro visível também despertam novamente a consciência do pertencimento naqueles indivíduos pertencentes à confissão cujas necessidades religiosas ficaram adormecidas durante muito tempo, durante o seu isolamento. Nesse sentido, a Igreja católica supera em muito a protestante. Na diáspora, ela não espera por uma comunidade propriamente formal de pessoas para proceder à constituição espacial; mas inicia esta última em torno do núcleo mínimo que houver, e essa localização se tornou inúmeras vezes o ponto de cristalização de uma vida comunitária interna e numericamente crescente. Por toda parte, as cidades funcionam como pontos de rotação de transações para o seu entorno mais próximo e mais distante; isto é, cada uma faz com que se gerem em seu interior inúmeros pontos de rotação, permanentes ou variáveis, para ações de transação. As transações exigem tanto mais das cidades quanto mais intensas elas forem, revelando assim toda a diferença de sua vivacidade em relação à inquieta agitação nômade de grupos primitivos. É o contraste típico entre as vivacidades sociais, se elas simplesmente significam um ímpeto para fora daquilo que é espacial e objetivamente dado, ou então o circuito de pastos rotativos dos povos pastoris; ou se giram em torno de pontos fixos. Apenas no último caso é que tais vivacidades são propriamente formadas, ganham um ponto de cristalização para o estabelecimento de valores permanentes, mesmo quando esses vigem apenas na forma persistente de relações e movimentos. Esse contraste entre suas formas de agitação domina, em geral, a vida externa e interna de modo tão variegado 
que a sua realização espacial aparece como um mero caso especial. Se relações espirituais ou sociáveis possuem um centro fixo em torno do qual circulam interesses e conversas, ou se simplesmente fluem seguindo a forma linear do tempo; se dois partidos políticos têm um ponto fixo entre eles, quer se trate da identidade constante de uma tendência ou de uma oposição constante, ou se a sua relação se desenvolve caso a caso, sem pré-conceitos; se em cada ser humano prevalece um sentimento de vida de matiz fortemente unilateral - por exemplo, de cunho estético -, que congrega todos os interesses diversos da pessoa, tanto religiosos como teóricos, sociáveis assim como eróticos, que matiza uns em relação aos outros, que os mantém em uma esfera - ou se os interesses da pessoa se desdobram sem essa retrovinculação constante e medida orientadora, apenas em conformidade com as suas próprias condições de força: isso condiciona visivelmente as maiores diferenças entre os esquemas de vida e determina, por meio de lutas e misturas constantes dessas vivacidades opostas, o curso real de nossas existências. Isso tudo, porém, são configurações individuais desse mesmo contraste geral ao qual, no espacial, pertence o ponto de rotação. É pelo fato de as transações transformarem a cidade em tal ponto, que emerge o verdadeiro sentido do trânsito: pois, em oposição ao simples ímpeto em direção ao ilimitado, esse sentido reside em que o movimento vá ao encontro de um segundo poder equivalente, sem que esse contato/encontro precise ser hostil - o que ele, antes do trânsito já formado, sempre é. Ora, tal encontro não significa mais um refregar-se recíproco, mas um complementar-se e, assim, um multiplicar-se das forças, que precisa do ponto de apoio espacial e, por isso, o gera.

Além disso, relembro o rendez-pous como forma especificamente sociológica cuja determinação local a linguagem caracteriza através do sentido duplo da palavra: rendez-vous designa tanto o próprio encontro como o seu lugar. A essência sociológica do rendez-vous reside na tensão entre a pontualidade e fugacidade da relação, por um lado, e em sua fixação espaço-temporal, por outro. $\mathrm{O}$ rendez-vous - e de modo algum apenas aquele erótico ou ilegítimo - destaca-se psicologicamente da forma crônica da existência pelo traço do único, do palpitante, que brota apenas na ocasião especial; e, por se desprender assim como uma ilha do decurso contínuo dos conteúdos da vida, ele ganha um suporte especial para a consciência precisamente nos fatores formais de seu tempo e de seu lugar. Por ser o que é sensorialmente mais visível, o lugar gera habitualmente, para a lembrança, uma força associativa maior que o tempo; de modo que, em particular quando se trata de uma relação recíproca única e de fortes emoções, é justamente o lugar que, para a lembrança, costuma ligar-se de modo indissolúvel a ela. E assim, como isso ocorre reciprocamente, o lugar continua permanecendo o ponto de rotação em torno do qual o lembrar enreda os indivíduos em relações recíprocas agora tornadas ideais.

Essa significação sociológica do ponto fixado no espaço já se aproxima de uma outra que seria possível designar como individualização do lugar. Parece um fato indiferente e superficial que as casas citadinas na Idade Média fossem, 
de modo muito geral e frequentemente ainda até bem avançado o século XIX, designadas por meio de nomes próprios: ainda há 50 anos os moradores do Faubourg St. Antoine em Paris teriam chamado as suas casas por nomes próprios (Au roi de Siam, Étoile d'or etc.), apesar da numeração já existente. Contudo, na diferença entre o nome individual e o mero número da casa se encontra expressa uma diversidade na relação do proprietário e do morador com a casa - e, portanto, com o seu entorno. Determinação e indeterminação da designação aqui estão mescladas num grau todo peculiar. A casa designada por meio do nome próprio deve dar àquelas pessoas uma sensação de individualidade espacial, de pertencimento a um ponto espacial qualitativamente fixado. Devido ao nome que está associado à representação da casa, essa conforma muito mais uma existência em si própria, individualmente matizada, possuindo, para o sentimento, uma espécie de unicidade mais elevada do que no caso da designação por números, que se repetem de modo homogêneo em cada rua, e entre os quais existem apenas diferenças quantitativas. Perante as flutuações e nivelações das transações sociais, particularmente as da cidade, essa espécie de nomeação documenta inconfundibilidade e personalidade da existência com respeito ao seu lado espacial, mas cujo preço, em comparação com as condições atuais, é obviamente uma indeterminação e uma carência de fixação objetiva; e por isso, essa espécie de nomeação precisa desaparecer quando as transações ultrapassam certa extensão e agilidade. A casa nomeada não é localizável imediatamente, sua localização não pode ser construída objetivamente, como no caso da designação geográfica atual. Como numerais ordinais, os números significam, afinal, apesar de toda a sua indiferença e abstração, um determinado ponto no espaço, o que $o$ nome próprio da localidade não faz. O grau mais extremo é então, por um lado, a designação dos hóspedes de um hotel pelo número de seu quarto; por outro, o fato de que também as ruas deixam de ser nomeadas para serem numeradas em sequência contínua, como acontece parcialmente em Nova York. Esse contraste entre as espécies de denominação revela, na esfera do espacial, uma oposição completa na posição sociológica de cada um. O ser humano individualista, com sua fixidez qualitativa e a inconfundibilidade de seus conteúdos de vida, escapa, precisamente por isso, ao alinhamento em uma ordem vigente para todos, na qual teria uma posição perfeitamente calculável conforme um princípio invariável. Onde, inversamente, a organização da totalidade regula o desempenho de cada um conforme uma finalidade que não reside nele mesmo, a posição dele tem que ser fixada conforme um sistema que é exterior a ele mesmo. O que lhe determina essa posição não é uma norma interna ou ideal, mas a sua relação com o todo, e, por isso, o modo mais apropriado de determinar tal posição é recorrer a uma ordem numérica. A solicitude automática para servir que é própria do garçom ou do cocheiro - cuja não individualidade ressalta precisamente do fato de que o conteúdo de tal solicitude não é, afinal, tão mecanicamente regular como aquela de um trabalhador de máquinas - é ressaltada, por isso, de modo bem acertado através da numeração deles, em vez de qualquer designação pessoal. É 
essa diferença sociológica que aquelas designações variadas das casas representam, nas relações dos elementos citadinos projetadas sobre o espaço.

Se aqui, portanto, a individualidade dos elementos da relação espacial não se deixava unificar, num mesmo símbolo, vinculada a um círculo amplo e variado, talvez seja possível, contudo, estabelecer, com base nesse padrão e em termos meramente formais, uma escala sociológica. Isto é: a individualidade, caráter de unicidade pessoal, por assim dizer, que o lugar de certas pessoas ou grupos possui, impede ou favorece, nas misturas mais variadas, que a partir de tal lugar se estabeleçam relações de amplo alcance com uma variedade de outros elementos. É a Igreja católica que alcançou a unidade mais perfeita de ambas as determinações através da sua sede em Roma. Por um lado, Roma é única por excelência, a figuração histórico-geográfica mais incomparável, e devido ao fato de que "todos os caminhos levam a Roma", ela é definida por um sistema de coordenadas incontavelmente numerosas; mas, por outro lado, ela perdeu completamente a restrição de sua localização em um ponto, devido ao imenso volume e conteúdo de seu passado, devido ao fato de aparecer como lugar geométrico de todas as mudanças e contrastes da história, cujo sentido e cujos vestígios confluíram como que visivelmente nele ou para ele: por isso, Roma perdeu completamente a estreiteza da localização em um ponto. É verdade que, devido ao fato de possuir Roma, a Igreja tem um domicílio local permanente, com todas as vantagens ligadas ao fato de ser constantemente encontrável, ligadas à continuidade sensorial-visível, à centralização segura de suas efetividades e de suas próprias instituições; contudo, ela não precisa pagar por isso com todas as outras dificuldades e unilateralidades das localizações de poder num único ponto individual, já que Roma não é, por assim dizer, nenhum lugar definido. Em seus efeitos psíquico-sociológicos, ela se estende para bem além de sua fixação local, pela vastidão dos destinos e das significações nela investidos, enquanto, contudo, também oferece à Igreja precisamente a determinação de tal fixação. Para sustentar os propósitos da Igreja em suas relações de dominação sobre os fiéis, Roma possui a individualidade e a unicidade mais extremas, que lugar algum jamais possuiu, e, ao mesmo tempo, a sublimidade de estar acima de qualquer restrição e contingência da existência individualmente fixada. Organizações grandes necessitam, como tais, de um centro espacial; é que elas não podem prescindir de um ordenamento superior e inferior, e quem dá as ordens tem, via de regra, de contar com um local de residência fixo para, por um lado, ter à mão seus subordinados, e para que, por outro lado, esses saibam onde encontrar o patrão em qualquer momento. Já onde não existe a união maravilhosa entre localização e supraespacialidade, como no caso de Roma, isso tem sempre de ser pago com certas renúncias. Originalmente, os franciscanos foram existências completamente desprovidas de um lar fixo; isso foi exigido por sua liberdade individualista em relação a todos os vínculos terrenos, por sua pobreza, por sua missão pregadora. Apenas quando a ordem amplamente expandida passou a precisar de "ministros", estes precisaram, pelos motivos aludidos, de uma resi- 
dência fixa, e, por isso, os frades doravante não puderam prescindir da fixação em mosteiros. Por mais que isso tenha servido tecnicamente ao seu poder, reduziu, contudo, aquele desprendimento incomparável, aquela segurança interna dos primeiros frades, dos quais se dizia que eles, de fato, não tendo nada, tudo possuíam. Ao passarem a compartilhar com os outros seres humanos a solidez das residências, a sua forma de vida foi trivializada, sua liberdade passava a ser apenas muito grande, mas não mais infinita, já que agora eles ao menos estavam fixados em um ponto espacial.

De modo completamente distinto de Roma operou, enfim, a localização de resto comparável por vários lados - do culto judaico em Jerusalém. Enquanto existia o templo de Jerusalém, partia dele como que um fio invisível até cada um dos judeus dispersos em inúmeros lugares, com sua variedade de cidadanias, interesses, idiomas e mesmo nuances de fé; ele era o ponto de encontro que intermediava os contatos em parte reais, em parte ideais de toda a comunidade judaica. Contudo, ele possuía uma determinação pela qual a individualização local se tensionava de modo mais agudo do que a romana, e que a sobretensionava: apenas aqui podiam ser feitos os sacrifícios, Javé não contava com outro local de sacrifício. Por isso, a destruição do templo teve de cortar esse vínculo; a força e o matiz específicos que o culto de Javé havia adquirido através da espacialização bem singular, cederam lugar, então, a um deísmo de cores mais opacas. Assim, a separação por parte do cristianismo transcorreu de modo mais fácil e mais forte, as sinagogas autônomas assumiram o lugar do ponto central que era Jerusalém, a coesão efetiva dos judeus foi retrocedendo cada vez mais do fator religioso para o fator racial. Essas foram as consequências daquela extrema intensificação local, que defrontou o vínculo sociológico com uma opção inflexível: aqui ou em parte alguma.

D. É através da proximidade ou distância sensoriais entre as pessoas em quaisquer relações umas com outras, que o espaço oferece um quarto tipo de condições externas que se traduzem na vitalidade das interações sociológicas. Um primeiro olhar convence de que duas associações mantidas juntas por interesses, forças, concepções exatamente iguais, mudarão de caráter em conformidade com o fato de os seus membros estarem em contato espacial ou separados uns dos outros. E isso, não apenas no sentido evidente de uma diferença na totalidade das relações - acrescentando-se àquela condição ainda outras, internamente independentes dessa e que se desenrolam devido à proximidade corporal -, mas no sentido de que as interações espacialmente fundamentadas não deixam de modificar essencialmente a primeira relação, também possível a distância. Uma cartelização econômica assim como uma amizade, uma associação de filatelistas, assim como uma comunidade religiosa podem prescindir de modo permanente ou temporário do contato pessoal; mas imediatamente se revela a possibilidade de inúmeras modificações quantitativas e qualitativas do vínculo coesivo, quando esse não precisa superar nenhuma distância. Antes de tratar dessa possibilidade, ressalte-se o fato geral de que, em princípio, a diferença 
entre ambas as espécies de vínculo é mais relativa do que faz supor a rudeza lógica do contraste entre o estar junto e o estar separado. O efeito psicológico do primeiro pode, de fato, ser substituído de modo muito aproximativo pelos meios da comunicação indireta, e ainda mais pela fantasia. Precisamente os polos das vinculações humanas contrárias em sentido anímico - o puramente objetivo-impessoal e o totalmente voltado para a intensidade do ânimo - conseguem realizar isso com mais facilidade: os primeiros, por exemplo certas transações econômicas ou científicas, porque seus conteúdos podem ser exprimidos por inteiro por formas lógicas e, precisamente por isso, por escrito; os outros, como associações religiosas e algumas de sentimento, porque a força da fantasia e a devoção do sentimento superam as condições de tempo e espaço de um modo que, com bastante frequência, aparenta ser místico. Na medida em que esses extremos perdem a sua pureza, a proximidade local se torna mais necessária: ou seja, quando aquelas relações objetivamente fundamentadas apresentam lacunas que só podem ser preenchidas por imponderabilidades não captáveis pela lógica, ou quando as relações puramente interiores não podem prescindir de um complemento de necessidades sensoriais exteriores. Talvez seja possível ordenar, desse ponto de vista, a totalidade das interações sociais em uma escala: qual o grau de proximidade ou distância espacial que uma sociação de formas e conteúdos dados ou exige ou tolera. O modo como seria possível combinar os critérios de tal escala continuará a ser exemplificado a seguir.

Sob iguais condições de sentimentos e de interesses, a capacidade de tensão espacial de uma sociação depende do grau existente da capacidade de abstração. Quanto mais primitiva a consciência, mais incapaz ela será de imaginar o mútuo pertencimento do espacialmente separado ou o não pertencimento mútuo do espacialmente próximo. Nesse ponto, a espécie das forças de sociação remonta imediatamente aos fundamentos últimos da própria vida do espírito; a saber, ao fato de que a uniformidade ingênua da imaginação não desenvolvida ainda não distingue de forma alguma bem entre o eu e seu entorno. Por um lado, sem acento individualista, o eu ainda se dilui nas imagens dos outros seres humanos e das coisas, como mostram a falta do eu na criança e a indiferenciação meio comunista de estados sociais primevos. Por outro lado, nesse estágio não é atribuído aos objetos um ser-para-si: o egoísmo ingênuo da criança e do homem natural quer se apropriar, sem mais, de tudo o que deseja - e ele deseja quase tudo o que dele se aproxima em termos sensoriais -, estendendo assim a esfera do eu de maneira praticamente igual por sobre as coisas, como ocorre, em termos teóricos, através do subjetivismo do pensar e da ignorância de regularidades objetivas. Fica evidente, assim, quão decisivo deve ser, nessas condições anímicas, a proximidade sensorial para a consciência do mútuo-pertencer. Como essa proximidade obviamente não entra em questão como fato espacial objetivo, mas como superestrutura anímica a ele superposta, ela pode ocasionalmente ser substituída nesse estágio, como já mencionado, por outras constelações psicológicas: por exemplo, pelo pertencimento à mesma agremiação totêmica, que en- 
tre os aborígenes australianos põe em estreita relação indivíduos de grupos que vivem completamente separados, de modo que eles, no caso de uma luta entre os respectivos grupos, saem uns do caminho dos outros. Em geral, contudo, na consciência primitiva apenas os contatos exteriores são os suportes daqueles internos - não importa quão diferentes eles sejam em seu caráter -; a imaginação indiferenciada não sabe bem distinguir os dois: como aliás, ainda hoje, no atraso das condições das cidades pequenas, a relação com o vizinho de casa e o interesse por este desempenham um papel bem diverso do que na cidade grande; nesta, pela complicação e confusão da imagem externa da vida, é-se acostumado a abstrações constantes, à indiferença em relação ao espacialmente mais próximo e ao vínculo estreito com o espacialmente muito distante. Em épocas nas quais a abstração que transpõe o espaço é exigida por circunstâncias objetivas, mas obstruída pela falta de desenvolvimento psicológico, geram-se, por isso, tensões sociológicas de consideráveis consequências para a forma da relação. Por exemplo, foi com razão que se atribuiu o patronato do rei anglo-saxão sobre a Igreja à grande distância da Santa Sé romana. Nessa época, a presença pessoal ainda era por demais sentida como condição para o exercício da autoridade, para que essa pudesse ser legada de bom grado a uma instância tão longínqua. Aliás, quero também supor uma retroação histórica, nesse contexto. Onde a superioridade espiritual de uma parte ou a coerção das circunstâncias tornam incontornáveis relações a uma distância para cuja transposição a consciência na realidade ainda não está madura, isso deve ter contribuído muito para o desenvolvimento da abstração, da extensibilidade do espírito, por assim dizer. A necessidade sociológica teve que criar o seu órgão psicológico-individual. Assim, sem dúvida, lá onde a relação da Europa medieval com Roma não falhou devido à distância espacial, essa mesma relação se tornou, precisamente por causa dessa distância, uma escola do poder de abstração, da capacidade de sentir para além do sensorialmente mais próximo; do triunfo dos poderes que apenas através de seu conteúdo se exercem de maneira efetiva sobre aqueles que dependem da presença espacial.

Se, portanto, relações de longa distância pressupõem, em primeira linha, um certo desenvolvimento intelectual, o caráter mais sensorial da proximidade local se manifesta, pelo contrário, no fato de que se costuma estar em pé de amizade ou de hostilidade - em suma, num pé decididamente positivo - com vizinhos estreitos, e a indiferença recíproca costuma estar excluída conforme o grau da estreiteza espacial. A intelectualidade dominante sempre significa uma redução dos extremos emocionais. Conforme o seu conteúdo objetivo, e igualmente como função anímica, a intelectualidade dominante se coloca para além das oposições entre as quais oscilam o ânimo e a vontade; ela é o princípio da imparcialidade, de modo que nem indivíduos nem épocas históricas de matiz essencialmente intelectualista costumam se destacar pela unilateralidade ou a intensidade de amor e ódio. Essa correlação também vale para as relações individuais entre as pessoas. A intelectualidade, por mais que ofereça um solo de comunicação geral, estabelece, contudo, precisamente por isso uma distância 
entre as pessoas: por possibilitar aproximação e consonância entre os mais distantes, ela gera uma objetividade fria e, muitas vezes, estranhadora entre os mais próximos. Se as relações com os espacialmente distantes costumam evidenciar certa tranquilidade, ponderação, ausência de emoções fortes, ao pensamento ingênuo isso parece igualmente uma consequência imediata da distância, precisamente como tal pensamento considera decorrente da mera extensão espacial o enfraquecimento de um movimento de projétil, na medida do espaço percorrido. Na realidade, o significado do intervalo espacial apenas consiste no fato de que elimina excitações, atritos, atrações e repulsões que a proximidade sensorial provoca, assegurando assim, no âmbito do complexo dos processos anímicos geradores da sociação, uma maioria aos processos intelectuais. Frente ao espacialmente próximo, com o qual o contato se realiza nas bilateralmente mais diversas situações e disposições, sem a possibilidade de cautela e escolha, costuma haver apenas sensações determinadas, de modo que essa proximidade pode ser o fundamento tanto da felicidade mais transbordante como da coerção mais insuportável. É uma experiência muito antiga o fato de que moradores de uma mesma casa podem estar apenas em pé de amizade ou de hostilidade. As exceções a essa regra confirmam o seu fundamento: por um lado, em casos de um nível educacional muito alto, por outro, na cidade grande moderna, podem ocorrer a completa indiferença e exclusão de qualquer reação emocional recíproca, quando a vizinhança, num corredor compartilhado, é absolutamente próxima. No primeiro caso, porque a intelectualidade predominante diminui as reações impulsivas aos - por assim dizer - estímulos de contato; no segundo, porque os contatos incessantes com inúmeras pessoas geram precisamente o mesmo efeito por embotamento: a indiferença em relação ao espacialmente próximo é simplesmente um dispositivo de proteção sem o qual seria inevitável desgastar-se e rebentar animicamente, na cidade grande. Onde temperamentos demasiadamente vívidos reagiram contra essa consequência enfraquecedora da vida na cidade grande, ocasionalmente se procuraram outros dispositivos de proteção: na Alexandria do período imperial, dois dos cinco quarteirões da cidade eram habitados principalmente por judeus, procurando-se, como isso, prevenir tanto quanto possível conflitos entre vizinhos por meio de procedências bilateralmente controladas. Se, por essa razão, o pacificador de dois partidos passionalmente em colisão procura, antes de qualquer coisa, separá-los espacialmente, isso não contradiz ao fato de que ele se esforça por precisamente aproximá-los, depois de eles estarem distantes um do outro. Porque, em alguns temperamentos, a fantasia tornada efetiva a distância desencadeia um excesso desenfreado de sentimentos, em relação ao qual as consequências estimulantes da proximidade sensorial, por maiores que sejam, não deixam de parecer simultaneamente de algum modo limitadas e finitas.

Além dos efeitos práticos evidentes da proximidade espacial, e da consciência, sociologicamente de extrema importância, de ao menos se ter tais efeitos à disposição em qualquer momento (mesmo que no instante atual não se faça uso 
efetivo deles); além desses efeitos, as consequências da proximidade para a forma de sociação se compõem do significado de cada um dos sentidos com os quais os indivíduos se percebem reciprocamente. Essa atividade dos sentidos para a vinculação dos seres humanos entre si deveria ser objeto de estudos específicos, que, devido a seus fundamentos bastante abrangentes de natureza fisiológica e psicológica, não podem ser inseridos aqui. Apenas a título de exemplo menciono alguns aspectos. Quando o estar junto é tal que os indivíduos se veem permanentemente, mas só podem falar uns com os outros em ocasiões relativamente raras, como os trabalhadores num galpão de fábrica ou os estudantes de uma aula expositiva ou os soldados de uma divisão habitualmente não separada, aí a consciência de unidade terá um caráter mais abstrato do que quando esse estar junto também implica simultaneamente comunicação oral. Em face da imagem óptica da pessoa ou das pessoas, a qual sempre mostra um conteúdo relativamente estável e apenas variável dentro de limites estreitos, o ouvido transmite uma abundância ilimitada das mais divergentes disposições, emoções, pensamentos; em suma, toda a polaridade da vida subjetiva assim como objetiva. A proximidade conversacional gera uma relação muito mais individual do que a proximidade visual, e isso não apenas porque ela acaba por ser somar a essa, mas de modo totalmente imediato: pouquíssimas pessoas retêm uma imagem visual exata daqueles que lhes são mais próximos, mesmo que os tenham diante dos olhos todo dia; sequer conseguem indicar de modo certeiro, na lembrança, a cor de seus olhos ou o formato de sua boca. Em compensação, a lembrança do dito é infinitamente mais rica e sólida, e, na verdade, estabelece por si só a imagem da personalidade como totalmente única e pessoal. Por isso, lá onde apenas o sentido visual aproveita a proximidade, surgirá mais provavelmente o sentimento de uma unidade geral-conceitual, não específica, ou também uma justaposição mecânica, enquanto a possibilidade do falar e do ouvir resulta em sentimentos de unidade individuais, animados, orgânicos. É de grande importância para a ligação ou repulsão entre seres humanos o olfato, que aqui forma uma escala com os outros dois sentidos, na medida em que liga a condição mais opaca, mais instintiva, mais exclusivamente emocional de tais contextos à proximidade corporal. A visão, por si só, dá motivos mais claros, mais conscientes, mais diferenciados para a associação ou o seu oposto. A audição realmente entrelaça as pessoas entre si; só ela é o suporte duradouro das associações que têm uma história, enquanto os outros sentidos só deixam em contato aquele ser dos seres humanos que é mais ou menos não desenvolvido. É ao olfato e, particularmente, aos estímulos dele que são subliminares à consciência e indesignáveis com palavras (pois só possuímos noções para as nuances olfativas grosseiras e não individuais), que poderemos atribuir certamente uma parte daquelas simpatias e antipatias elementares que se travam unilateral ou reciprocamente entre as pessoas, muitas vezes para além de toda a compreensibilidade. No mínimo, o olfato tem uma grande parcela na relação sociológica entre várias raças que vivem no mesmo território: a aceitação dos negros nas esferas superiores da sociedade norte-americana está 
fora de cogitação já por causa da atmosfera do negro; ${ }^{14}$ a aversão muitas vezes instintiva entre judeus e germânicos foi imputada ao mesmo fator; o contato pessoal entre cultos e trabalhadores, que na atualidade muitas vezes tem sido tão vividamente recomendado; essa aproximação, também reconhecida como ideal ético pelos cultos, dos dois mundos sociais "dos quais um não sabe como vive o outro": tudo isso falha simplesmente na impossibilidade de superação das impressões sensoriais desse campo. Em prol do interesse moral-social, o culto mediano preferirá, antes, enfrentar todas as privações possíveis ao invés do contato físico com o povo, no qual gruda "o suor honesto do trabalho". Dessa maneira, a proximidade espacial influencia muito consideravelmente a figuração sociológica no mínimo em sentido negativo, e provavelmente, com um maior grau de cultura, cada vez mais, porque esta última reduz a verdadeira acuidade de percepção para todos os sentidos, e não em menor grau para o olfato, aumentando contudo a ênfase no prazer ou desprazer. Pode-se designar o olfato diretamente como sentido dissociativo, já que o estar junto de muitos nunca lhe oferece quaisquer atrações, tal como precisamente essa situação é capaz de gerá-las para os outros sentidos, ao menos sob certas circunstâncias. Já através dessa mediação físico-psíquica, o refinamento cultural aponta para o isolamento individual, ao menos em países mais frios; enquanto, por sua vez, a oportunidade de viabilizar o estar junto essencialmente ao ar livre, portanto sem aquele inconveniente, deve ter influenciado de modo considerável as transações sociais em países meridionais - mesmo que, naturalmente, também em conjunto com a cooperação ou concorrência de uma centena de outras causas.

Ao lado dessas consequências psicológicas no sentido mais estrito de proximidade ou distância para as interações sociais, colocam-se, naturalmente, outras de essência mais lógica ou, ao menos, de cunho racional, que não têm nada a ver com aquela imediatez sensorial-irracional. As mudanças, por exemplo, que uma relação experimenta devido à passagem de seus elementos da distância à proximidade espacial, de modo algum consistem apenas na intensidade crescente do vínculo, mas igualmente em enfraquecimentos, reservas, repulsões. Ao lado das antipatias diretas que podem brotar da proximidade sensorial, operam aqui sobretudo a ausência ou o desmentido das idealizações, com as quais se reveste o companheiro imaginado de modo mais ou menos abstrato; operam a ênfase necessária na distância interior, a separação dos limites das esferas pessoais, a defesa contra intimidades inconvenientes; em suma, contra tais perigos que nem entram em questão no caso de distância espacial; operam certas cautelas e desvios que as transações sociais têm de realizar justamente em caso de imediatez pessoal, porque as transações sociais indiretas ou a distância costumam possuir uma objetividade maior, uma atenuação de recrudescimentos pessoais, uma probabilidade menor de precipitações e impetuosidades. Pertence às tarefas sociológicas mais delicadas da arte de viver, salvar para uma relação de proximidade os valores e as sutilezas que se desenvolvem entre personalidades a uma certa distância. Involuntariamente se concluirá que o calor e a intimidade da 
relação deveriam aumentar, na medida da aproximação pessoal. O que, no caso mais favorável, de fato poderia se desenvolver, a pessoa antecipa já no início, no tom e na intensidade das transações, para então sentir com frequência suficiente, certamente, que exigiu demais da mera forma da relação espacial. Agarramos o vazio, porque o caráter súbito da proximidade corporal nos enganou acerca da lentidão com que a proximidade anímica segue aquela. Assim, surgem reveses e arrefecimentos que não só revogam tal excesso ilusório, mas que também arrastam consigo os valores anteriormente já conquistados do amor ou da amizade, ou da comunidade de interesses ou da comunicação espiritual. Essa situação faz parte das confusões não raras entre seres humanos, que certamente podem ser evitadas de antemão por meio de sentimentos instintivos de tato; mas que, uma vez geradas, em geral não se deixam mais endireitar apenas por meio de tais sentimentos, mas apenas sob a assistência de ponderações e contemplações conscientes.

Depreendo um segundo exemplo do conjunto das relações que se afastam muito da intimidade dos vínculos há pouco abordados, a fim de inquirir as diferenças sociológicas das distâncias espaciais em relação a seus resultados calculáveis. Lá onde, num grupo maior, se encontra uma minoria que é mantida coesa por interesses iguais, faz uma grande diferença, para o comportamento de tal minoria em relação ao todo, se ela coabita de forma espacialmente compacta, ou se vive dispersa no interior da totalidade do grupo, ou em divisões pequenas. Não é possível determinar de modo geral qual das duas formas é a mais apropriada para a posição de poder de tal minoria, em condições de resto iguais. Se o subgrupo em questão se encontra num estado defensivo frente à maioria, $\mathrm{o}$ que decide essa questão é o grau de suas forças. Se estas são muito parcas, de modo que não entra em questão uma verdadeira resistência, mas apenas fuga, um fazer-se-invisível, uma evitação de ataques aniquiladores, então será aconselhável a maior dispersão possível, o que é não é difícil de reconhecer. No caso de forças mais consideráveis, particularmente um número maior de pessoas para as quais já se põe a chance de resistir a um ataque, é, inversamente, a maior aglomeração possível que promoverá a conservação. Assim como já os cardumes dos arenques se protegem de perigos por meio de sua compacidade densa, oferecendo desse modo uma superfície menor para ataques, e menos interstícios para inimigos invasores, assim a coabitação estreita de minorias expostas proporciona uma probabilidade maior de resistência bem-sucedida, de ajuda mútua, de uma consciência mais eficaz do mútuo pertencimento. O modo de distribuição espacial dos judeus fez uso de ambas as vias, para proveito deles. Como a diáspora os dispersou pelo mundo cultural inteiro, nenhuma perseguição foi capaz de atingir todas a suas divisões, e, para quem a vida se tornou impossível em um ponto, sempre houve outro de adesão, proteção e apoio. Por outro lado, devido ao fato de que, nos respectivos lugares, eles viviam ou no gueto ou, de resto, na maioria das vezes em total vizinhança, também gozavam das vantagens e forças que a coligação compacta, sem vácuos, desenvolve em prol de sua defesa. Uma 
vez que as energias tenham chegado ao estágio de poderem avançar também para ataques, para ganhos de vantagens e de poder, a relação se inverte: nesse patamar, uma minoria concentrada não poderá realizar tanto quanto uma que coopera a partir de vários pontos. Enquanto, por isso, nesse estágio de forças menores e, por isso, essencialmente dependentes de defesa, o gueto é decisivamente vantajoso e intensificador de força, ele aparece como extraordinariamente comprometedor quando a segurança e a energia da comunidade judaica já estão ampliadas; e a dispersão desta pela totalidade da população aumentou o seu poder coletivo da maneira mais eficaz possível. Isso é um dos casos não demasiado raros nos quais o aumento absoluto de um quantum inverte diretamente as relações dentro dele.

Já quando não se considera a minoria o elemento variável com respeito a sua estrutura, mas se pergunta, dada uma determinada dispersão ou compacidade espacial de tal minoria, pela constituição das totalidades envolventes, resulta daí a seguinte tendência necessária: uma formação particular pequena no interior de um grupo abrangente, mantido coeso por um poder central, favorecerá uma forma de governo individualizante, cedente da autonomia das partes, no caso de compacidade espacial. Pois, onde tal parte não sabe cuidar de seus interesses por si própria, onde ela não consegue viver a vida conforme normas próprias, ela não tem qualquer possibilidade técnica de se proteger contra violações por parte da totalidade. Um regime parlamentar, por exemplo, que sempre submete a vida própria das partes a meras decisões de maioria, simplesmente tornará tal minoria maioria. Mas, quando essa mesma minoria vive dispersa, de modo que não há como falar de desenvolvimento autônomo, de poder imediato, de instalações próprias, a autonomia das divisões locais do todo não terá valor para ela, já que em nenhuma dessas a minoria em questão chega a alcançar uma maioria. Ao contrário, ela terá uma atitude centralista, porque se tal minoria, nas condições de fracionamento de suas energias, pode ainda esperar alguma consideração favorável, esta lhe será dispensada mais provavelmente por um poder central unitário, talvez até absolutista. No caso de uma estrutura tão difusa, a minoria chegará a ter influência positiva apenas através das personalidades eminentes individuais que produzir; e, também para essa forma de poder, a maior chance se dará precisamente em face de um domínio que seja o mais poderoso e pessoal possível. A distância local dos membros os remete a um poder central, a sua compacidade os afasta dele.

As consequências dessa situação espacial são totalmente diferentes quando ela não afeta uma subdivisão, mas a totalidade de um grupo. Uma comunidade cujos elementos moram todos dispersos, não terá tão facilmente inclinações centralistas, caso não interfiram fortemente outras causas. Quando as comunidades rurais camponesas suíças, na Idade Média, formaram comunidades estatais, elas repetiram essencialmente, no processo, os traços fundamentais das constituições urbanas. No entanto, a cooperativa dos camponeses não foi, tal como a urbana, quase totalmente assimilada pelos órgãos por ela instituídos, mas a própria 
assembleia primária do povo continuou sendo o órgão mais importante para a jurisdição e o direcionamento de todos os assuntos públicos. Parece que aqui opera uma certa desconfiança porque, no caso de grandes distâncias, o controle permanente dos órgãos centrais é impraticável, e, de modo bem geral, opera uma vivacidade menor das interações sociais, em comparação com aquelas da população urbana compacta. Para esta, formações objetivas são necessárias como pontos fixos nas flutuações e atritos que a vida urbana gera, tanto através dos contatos permanentes como através das diferenciações sociais fortes, em gradação contínua, de seus elementos. Também quando a base for democrática, essas consequências das condições locais irão sugerir à população urbana um certo rigor na centralização.

A democracia realmente direta, no entanto, necessita da delimitação espacial estreita de seu círculo, tal como proclama o documento clássico do Federalista: "The natural limit of a democracy is that distance from the central point which will but just permit the most remote citizens to assemble as often as their public functions demand". ${ }^{15} \mathrm{E}$ a Antiguidade grega devia sentir como banimento quando a pessoa morava a tamanha distância do lugar das reuniões políticas que não podia participar delas com regularidade. Em torno desse interesse pela autonomia imediata, a democracia e a aristocracia se encontram, quando suas condições espaciais são as mesmas. A história espartana evidencia esse condicionamento numa combinação muito interessante. Lá se sabia muito bem que morar disperso em pleno campo favorecia o aristocratismo. É que, em tais condições locais, também as democracias adotam, devido a sua autossuficiência e sua independência em relação aos poderes centrais dominantes, uma espécie de caráter aristocrático, como a história das tribos germânicas mostra de modo bastante variegado. Por isso, quando os espartanos quiseram derrubar a democracia em Mantineia, eles dissolveram a cidade numa série de pequenas localidades. Eles próprios, porém, no conflito entre o caráter agrário de seu Estado (no qual a dispersão espacial permanecia sempre perceptível, e que, nesse sentido, também se ajustava perfeitamente bem ao aristocratismo dos espartanos) e a centralização enérgica (que o seu militarismo exigia), encontraram como saída deixar a sua agricultura por conta de servos, enquanto eles próprios moravam bastante concentrados em Esparta. O destino da nobreza francesa no Ancien Régime transcorreu apresentando certa semelhança externa com esse caso. No seu modo de vida agrário-extensivo, tal nobreza foi em grande medida autônoma, até que o regimento cada vez mais centralizado, com a sua culminação ostensiva na vida da corte de Luís XIV, por um lado, minasse a sua autonomia jurídica e administrativa e, por outro, a atraísse invariavelmente para Paris. Portanto, em contraste com a correlação das minorias opositoras, vale aqui a seguinte: à concentração local do grupo correspondem tendências centralistas; à dispersão local, inversamente, tendências autonomistas. E, já que essa relação aparece nos casos de completo contraste entre as tendências de vida social, tanto na tendência de cunho democrático como na de cunho aristocrático, conclui-se que o fator es- 
pacial da proximidade ou distância define a forma sociológica grupal de modo decisivo ou, ao menos, codecisivo.

E. De certo modo, todas as formações sociológicas até aqui consideradas retrataram a contiguidade inerte do espaço: a delimitação e a distância, a fixidez e a vizinhança são como continuidades das configurações espaciais para dentro da estrutura da humanidade, que se distribui no espaço. Esse último fato vincula consequências totalmente novas à possibilidade de que os seres humanos se movam de lugar em lugar. Devido a isso, os condicionamentos espaciais da existência dos seres humanos entram em fluidez. E, como a humanidade em geral só adquire por sua mobilidade a existência que conhecemos, resultam da mudança de lugar no sentido mais estrito, da itinerância, inúmeras consequências especiais para as suas interações, das quais algumas querem aqui ser esboçadas. Do ponto de vista sociológico, a divisão fundamental desses fenômenos é a seguinte: quais as formas de sociação que se estabelecem num grupo itinerante, à diferença de um grupo espacialmente fixado? E: quando, com efeito, não é o grupo como um todo, mas apenas alguns de seus elementos que se deslocam, quais as formas que daí resultam para o próprio grupo e as pessoas itinerantes?

1. As figurações principais do primeiro tipo são o nomadismo e aqueles movimentos que se designam como migrações dos povos. Desse modo, para o nomadismo a itinerância faz parte da substância da vida, o que se manifesta da melhor maneira na infinitude, forma circular de retorno sempre aos mesmos sítios; já no caso das migrações dos povos, a itinerância é percebida mais como um estado transitório entre duas formas de vida distintas - seja a forma a fixidez, seja a nômade a forma anterior das duas. Na medida em que a consideração sociológica apenas inquire o efeito da itinerância como tal, ela não necessita separar os dois tipos. Porque tal efeito sobre a forma de sociedade é tipicamente o mesmo em ambos os casos: opressão ou supressão da diferenciação interna do grupo; daí a falta de efetiva organização política, mas que, muitas vezes, é perfeitamente compatível com a monocracia despótica. Quanto à última constelação, cabe lembrar sobretudo da relação de circunstâncias patriarcais com o nomadismo. Lá onde aumenta, para os povos caçadores, a necessidade de se dispersar e se deslocar, o homem afasta sua mulher da vizinhança da família dela, privando-a, assim, do apoio dessa e colocando-a de um modo mais decisivo sob o seu poder, de maneira que, no caso dos índios norte-americanos, se chegou a responsabilizar diretamente a itinerância das famílias pela transição da organização matrilinear de parentesco para aquela patrilinear. Acresce que, nos verdadeiros nômades, a criação de gado assumiu o lugar da caça, e que, por toda parte, tanto esta como aquela são negócio dos homens. Devido a essa liderança masculina em relação à aquisição principal ou exclusiva de alimentos, cristaliza-se entre os nômades o despotismo do homem. Não apenas de uma maneira geral, contudo, o despotismo familiar e o estatal estão numa relação de geração recíproca, mas o nomadismo deve favorecer o último de um modo tanto mais decisivo, já que 
aqui o indivíduo não encontra amparo num chão firme. A mesma circunstância que, por toda a parte, torna os nômades sujeitos e objetos de ladroagem - a mobilidade da posse -, torna a vida em geral algo tão lábil e desenraizado que a resistência contra personalidades poderosas, aglutinantes, certamente não é tão forte quanto lá onde a existência de cada um está consolidada em sua gleba. $\mathrm{E}$ isso particularmente porque aqui não vem ao caso a chance de uma possível esquiva, a qual, como pouco mais adiante caberá ressaltar, foi, para os oficiais itinerantes de ofícios manuais, uma arma tão peculiar contra as tendências centralizadoras do Estado. Acresce, ademais, que tais aglutinamentos despóticos na maioria das vezes ocorrerão para fins bélicos, aos quais o nômade aventureiro e selvagem sempre estará mais disposto do que o agricultor. É verdade que, como dito, falta aos grupos nômades, via de regra, a organização rigorosa e sólida que, em outros casos, constitui a técnica dos despotismos bélicos. E, devido à ampla dispersão e à independência recíproca das diversas famílias nômades, nem existe disposição para tal organização. Afinal, qualquer organização mais fina e abrangente pressupõe divisões de trabalho, que, por sua vez, pressupõem um contato espacial ou dinâmico estreito entre os elementos. No entanto, o aglutinamento despótico por ocasião das itinerâncias massivas dos povos nômades - que não sulcaram menos a história europeia do que as da China, da Pérsia e da Índia - evidentemente não foi uma síntese organizada, mas o seu impacto residiu precisamente na agregação mecânica de elementos totalmente indiferenciados; agregação que se espalhou com a pressão constante e desprovida de interstícios de uma corrente de lama. Por isso, as planícies baixas e estepes que, por um lado, incitam à vida nômade e, por outro, são as regiões-fonte de grandes migrações tribais - a Europa oriental, a Ásia setentrional e central, as terras baixas americanas -, mostram os tipos raciais menos formados, e esse nivelamento etnográfico deverá ser tanto consequência quanto causa de um nivelamento sociológico. Existe uma relação de bases profundas entre o movimento no espaço e a diferenciação dos conteúdos sociais e pessoais da existência. Ambos apenas constituem satisfações diferentes de $u m$ lado das tendências anímicas antagônicas, cujo outro lado tende à tranquilidade, constância, unidade substancial do sentimento e da imagem da vida: as lutas e os acordos, as misturas e as predominâncias alternantes entre ambos podem ser usados como um esquema para que nele sejam inseridos todos os conteúdos da história da humanidade. $\mathrm{O}$ grau em que necessitamos da estimulação através de impressões diferentes, alternantes, pode se realizar dos dois modos: ou pela alternância das impressões, exigências e aventuras da vida itinerante; ou pela diferenciação das circunstâncias estáveis, a qual não apenas mostra à alma - quando esta olha a sua volta - todas essas alternâncias como que na forma da imanência, da contiguidade de fatores sociais, mas satisfaz a necessidade dessa mesma alma por diferença através da consciência de sua diferenciação em relação a qualquer outra - e de uma diferenciação distinta em relação a cada uma das almas restantes. A partir daí se torna compreensível, por um lado, como o aumento extraordinário da necessidade de diferença, nos seres 
humanos modernos, lança mão simultaneamente das duas formas; mas como, em outros casos, essas podem precisamente ser vicárias umas em relação às outras, de modo que sociedades estáveis no espaço se diferenciam fortemente em seu interior, enquanto aquelas itinerantes já têm recobertos de antemão os sentimentos de diferença necessários a sua condição nervosa, necessitando ademais, para a simultânea tendência vital do sinal oposto, de um nivelamento social.

A técnica da itinerância torna-se o suporte dessa circunstância fundamental. Os membros de uma sociedade itinerante dependem de maneira particularmente estreita uns dos outros, os interesses comuns têm, à diferença de grupos sedentários, mais a forma da momentaneidade. E, por isso, tais interesses recobrem, com a energia específica do atual, que tão frequentemente triunfa sobre o objetivamente mais essencial, as diferenças individuais no duplo sentido de diferença: como variedade qualitativa ou social, e como disputa e discórdia entre os indivíduos. Nas tribos nômades, os impulsos de expansão e contração espaciais estão em oposição fortemente contrastada, as condições de alimentação levam cada uma a se afastar tanto quanto possível da outra (e a separação espacial deve também operar no sentido de uma separação anímico-qualitativa), enquanto a necessidade de proteção, contudo, sempre volta a ajuntá-los, postergando a diferenciação. ${ }^{16}$ Livingstone conta das divisões entre os clãs africanos, ${ }^{17}$ que visivelmente não se sentem muito ligados uns aos outros em circunstâncias alheias às das itinerâncias da tribo toda, quando são muito solidários uns com os outros, apoiando-se reciprocamente. Da Idade Média há muitos relatos de que comerciantes que se deslocavam em conjunto teriam estabelecido entre eles ordenamentos totalmente comunistas, sendo apenas uma continuação disso o fato de que as corporações de comerciantes ou as hansas formadas no exterior frequentemente constituíram verdadeiras comunidades de vida, e aliás, de modo significativo, justamente no início de seu desenvolvimento. Ao lado do fator nivelador da itinerância não terá faltado também, nesses casos, o fator despótico. Ao menos em relação aos comboios de comerciantes itinerantes que, partindo de Palmira, no Império Romano, caminharam por toda a região do Eufrates, é ressaltado que os seus chefes teriam sido os homens mais conspícuos de uma nobreza antiquíssima, para quem os membros da caravana muitas vezes ergueram colunas de honra. É de supor, portanto, que o poder deles durante a viagem fosse discricionário, exatamente como aquele do capitão de navio em condições bem análogas, durante a navegação. Precisamente porque, tomado em si e por si, o deslocar-se individualiza e isola, porque relega o ser humano a si mesmo, ele o impele a coligações estreitas, vigentes para além das demais diferenças. Ao privar os indivíduos dos apoios da terra natal, mas ao mesmo tempo de suas gradações sólidas, ele lhes sugere precisamente preencher os destinos dos itinerantes, a solidão e o desamparo, com a maior coligação possível em prol de uma unidade mais do que individual.

Esse traço sociológico fundamental da itinerância se revela como formalmente sempre o mesmo em fenômenos que, em termos de conteúdo, não têm 
conexão nenhuma com aqueles aludidos até aqui. $\mathrm{O}$ conhecimento travado entre viajantes - enquanto realmente se tratar apenas disso, sem assumir um caráter que independa de sua espécie de vinculação inicial - muitas vezes desenvolve uma intimidade e franqueza para as quais, no fundo, não há, na verdade, como encontrar qualquer razão interna. Aqui, parecem operar em conjunto três fatores: o desprendimento do ambiente costumeiro, a comunhão das impressões e acontecimentos momentâneos, a consciência da separação iminente e definitiva. $\mathrm{O}$ intermediário desses fatores se explica facilmente, quanto a seu efeito unificador e uma espécie de comunismo espiritual, na medida justamente que essa identidade do vivenciar perdura e domina a consciência. Os dois outros fatores, porém, são acessíveis apenas a uma contemplação sociológica mais complexa. Quanto ao primeiro, é preciso ter clareza de quão poucas pessoas sabem, a partir puramente de seu interior e por instintos seguros, onde é que fica realmente o limite inalterável de sua propriedade anímica privada, quais reservas exige o seu ser individual para manter-se ileso. É apenas por choques e rejeições, por decepções e adaptações que costumamos experienciar, aos poucos, o que podemos revelar de nós aos outros sem deixar chegar a situações constrangedoras, sentimentos de indiscrição em relação a nós mesmos e prejuízos diretos. $\mathrm{O}$ fato de a esfera anímica do individuo não estar, de modo algum, delimitada de antemão de modo seguro em relação àquela dos outros, como ocorre com a esfera de seu corpo; o fato de esse limite nunca superar absolutamente a sua relatividade, mesmo depois de ter superado as flutuações de sua primeira formação: isso vem facilmente para o primeiro plano quando deixamos para trás as relações habituais - nas quais demarcamos para nós um distrito relativamente sólido por meio de direitos e deveres paulatinamente emergidos, pela compreensão dos outros e por sermos compreendidos, pelo teste de nossas forças e nossas reações emocionais. Desse modo, aqui sabemos com segurança o que nos cabe dizer e sobre o que nos cabe calar, e por meio de qual medida de ambos geramos e mantemos nos outros a imagem adequada de nossa personalidade. Agora, como essa medida relativa de exteriorização, fixada por meio da relação com o nosso ambiente, para muitas pessoas se solidifica como que numa relação absoluta, em si correta, tais pessoas perdem, via de regra, qualquer medida de seu dar-se quando em ambientes inteiramente novos, perante pessoas completamente estranhas. Por um lado, eles se veem metidos em sugestionamentos aos quais não conseguem de modo algum resistir, no desenraizamento em que se encontram; por outro lado, veem-se metidos em inseguranças internas, nas quais não conseguem mais pôr freio à intimidade ou confissão já incitadas, deixando-as rolar até o fim, como que num plano inclinado. ${ }^{18}$ Acresce a isso o terceiro fator: baixamos nossas reservas habituais tanto mais facilmente perante a pessoa com quem não teremos mais qualquer contato após essa revelação recíproca ou unilateral única. No caráter de sua forma e de seu conteúdo, todas as sociações são influenciadas do modo mais decisivo possível pela ideia da duração temporal a que se supõe que elas estejam destinadas. Isso pertence às percepções sociológi- 
cas cuja verdade é, sem dúvida, absolutamente óbvia para os casos mais crassos, mas que permanece tanto mais frequentemente desapercebida para os casos mais sutis. Que a essência qualitativa do vínculo entre um homem e uma mulher seja outra, num casamento vitalício, em comparação com uma relação fugaz; que o soldado profissional tenha outra relação com o exército do que um recruta que serve por um ou dois anos: isso é sem dúvida evidente para qualquer pessoa. Mas não parece se fazer válida em nenhum lugar a conclusão de que esses efeitos macroscópicos da quantidade temporal também teriam que ocorrer em casos de matéria relativamente menos evidente aos olhos, e como que microscopicamente. Se um contrato foi fechado por um ou dez anos; se uma convivência sociável é calculada por algumas horas noturnas ou por um dia inteiro, como, por exemplo, numa excursão campestre; se a reunião acontece à table d'hôte de um hotel que troca de hóspedes todo dia, ou naquela de uma pensão destinada a estadas mais longas: isso é absolutamente essencial para a coloração do transcurso dessa convivência, quando inteiramente idênticos, de resto, o material, as concepções, o caráter das pessoas de tal estar junto. Em que direção esse fator opera não se depreende, evidentemente, da quantidade de tempo em si; isso depende da totalidade das circunstâncias: a duração temporal mais longa se torna às vezes uma negligência, conduzindo como que a um deixar pendurado o laço coesivo, porque a pessoa se sente segura de si e não acha necessário continuar fortalecendo a ligação afinal irrevogável por meio de novos esforços; outras vezes, a consciência justamente dessa indissolubilidade nos induzirá a uma adaptação recíproca e a uma transigência mais ou menos resignada, para que a obrigação já assumida se torne ao menos tão suportável quanto possível. A brevidade do tempo ocasionalmente levará à mesma intensidade do aproveitamento da relação, como a extensão da mesma no caso de outros temperamentos, passíveis de suportar uma relação apenas externa ou "pela metade" por um tempo curto, mas não na longa duração. Essa alusão ao efeito que a ideia da duração de uma relação exerce sobre cada momento individual dessa, deve aqui evidenciar apenas que a essência sociológica do encontro de curta duração se insere em um contexto amplo e fundamental. Devido à sensação de que não obriga a nada, e de que a pessoa é, na verdade, anônima perante a outra da qual ela se separará para sempre em algumas horas, o conhecimento travado entre viajantes frequentemente seduz a confidências muito bizarras, a uma transigência incontida em relação ao impulso de exteriorização, que, nas relações costumeiras de longo prazo, apenas a experiência de suas consequências nos ensinou a represar. Assim, chegou-se a atribuir as oportunidades eróticas do estamento soldadesco ao fato de não possuir a sedentariedade da maioria dos outros estamentos; de que a relação com o soldado possui, para a mulher, a coloração de um sonho fugaz que não apenas não compromete a nada, mas que, precisamente por sua brevidade, seduz à intensidade extrema de seu aproveitamento e da entrega a ele. Assim, chegou-se a explicar o sucesso dos frades mendicantes também pelo fato de que com eles, que tinham o direito de ouvir confissões em toda parte, e 
que chegavam num dia e no outro partiam, as pessoas se confessavam frequentemente menos constrangidas do que com o próprio pároco, que mantinha o confessando constantemente sob os olhos. Como tantas vezes, também aqui os extremos parecem possuir um certo significado uniforme, oposto ao da esfera intermediária: a pessoa se revela ao mais próximo e ao mais estranho, enquanto as camadas intermediárias formam o lugar da verdadeira reserva. Assim, pode-se perceber também nesses fenômenos largamente afastados um do outro o nexo fundamental formal, o desprendimento peculiar da pessoa como itinerante e perante o itinerante; justamente por isso uma entrega para além das barreiras habituais da individualização: aquilo que, acima, chamei de aproximação a um comunismo espiritual. Em inúmeras transformações, dificilmente identificáveis, vive esse motivo sociológico que, dentro do grupo itinerante, impele a um nivelamento, a uma uniformidade despersonalizadora.

2. Há que se contemplar de modo totalmente separado o modo como a itinerância de uma parte opera sobre a forma do grupo inteiro, de resto sedentário. Da multiplicidade de fenômenos pertinentes menciono aqui apenas dois, dos quais um acompanhará tais efeitos na direção da unificação do grupo, o outro precisamente na direção de seu dualismo. Para manter dinamicamente juntos, num grupo amplamente expandido, em termos espaciais, os elementos afastados entre si, épocas altamente desenvolvidas geram um sistema de meios variegados, que abrangem principalmente tudo aquilo da cultura objetiva que é uniforme. Tal uniformidade é acompanhada da consciência de que justamente aqui haveria o mesmo que há em qualquer ponto do mesmo círculo: a igualdade da língua, do direito, do modo geral de vida, do estilo dos edifícios e equipamentos; ademais, as unidades funcionais: a administração do Estado e da Igreja - centralizada, e que simultaneamente se estende por toda a parte; as agremiações dos empresários assim as como dos trabalhadores industriais, mais seletivas, porém mesmo assim transcendentes de todas as separações locais; as ligações comerciais dos atacadistas e varejistas; as ligações mais ideais, porém muito efetivas, dos companheiros de estudo, das associações dos veteranos de guerra, dos professores de escola, dos professores universitários, dos colecionadores de toda espécie. Em suma, um emaranhado de fios com centros absolutos ou parciais mantém juntas todas as partes de um Estado altamente cultivado - decerto, com uma energia distribuída de modo muito variado, já que nem a cultura substancial é bastante uniforme em termos de gênero e grau, nem as ligações funcionais direcionam, com o mesmo interesse e a mesma força, todos os elementos para o seu centro. Em todo caso, na medida em que essas unificações operam, elas só necessitam do movimento das pessoas por grandes distâncias espaciais em proporções reduzidas, e como que acidentalmente. A vida moderna consegue gerar a consciência da unidade social, por um lado, através daquelas uniformidades objetivas e do conhecimento dos pontos comuns de contato; por outro, através das instituições fixadas de uma vez por todas; em terceiro lugar, enfim, através da comunicação por escrito. Enquanto, contudo, faltam essa organização obje- 
tiva e essa técnica, tem importância proeminente um outro meio de unificação, que mais tarde recua: a itinerância, que decerto, devido a seu caráter puramente pessoal, não consegue nunca recobrir a extensão da região espacial do modo como aqueles meios, ou centralizar, em termos de conteúdo, o perímetro que eles centralizam. O comerciante e o letrado, o funcionário público e o artesão, o monge e o artista, os altos escalões assim como os elementos mais decaídos da sociedade, foram, em muitos aspectos, mais móveis na Idade Média e nos primórdios da Era Moderna, do que agora. O que nós ganhamos em consciência de mútuo pertencimento através de cartas e livros, da conta corrente e das sucursais, da reprodução mecânica de um mesmo modelo e da fotografia, naquela época precisava ser operado através do viajar de pessoas, que era tão deficiente nos resultados como desperdiçador na execução. Pois, onde apenas se trata de transmissões objetivas, o viajar de uma pessoa é uma extrema importunidade e indiferenciação, pois a pessoa tem justamente de carregar consigo, como tara, todo o exterior e o interior de sua personalidade, que não têm nada a ver com $\mathrm{o}$ assunto aqui em questão. E, ainda que se ganhasse, com isso, também o subproduto de certas relações pessoais e anímicas, precisamente isso não serviria ao propósito ora em foco: tornar sensível e efetiva a unidade do grupo. Relações objetivas, que de si próprias excluem tudo o que é pessoal, e que, por isso, a partir de um elemento específico podem conduzir a um número ilimitado de outros, conseguem, com muito mais profundidade, tornar consciente uma unidade que se expande por cima dos indivíduos. Precisamente a relação anímica com frequência não exclui todas as outras apenas em termos de conteúdo; mas ela se exaure a tal ponto, em sua estreiteza imediata, que resulta mínimo o seu rendimento para a consciência da unidade do círculo a que ambas as partes pertencem. É sintomático desse caráter subjetivo das ligações - e simultaneamente, aliás, também de sua importância - o fato de que, na Idade Média, a conservação dos caminhos e das pontes fosse considerada um dever religioso. $\mathrm{O}$ fato de que tantas relações agora objetivamente mediadas só se realizassem, em tempos passados, através da itinerância de personalidades, me parece uma razão para a fraqueza relativa da consciência de unidade, nos grupos extensos de outrora.

Em todo caso, as itinerâncias foram, em geral, muitas vezes o único, com frequência ao menos um dos suportes comparativamente mais fortes daquela centralização, especialmente no sentido político. De uma parte, era na forma de uma única viagem em circuito que o rei tomava pessoalmente posse das diversas partes de seu reino, como é relatado sobre os antigos francos, e como faziam os antigos reis da Suécia. De outra parte, era desse modo que o rei viajava pelo reino, ou periódica ou constantemente. Aquele foi o caso dos governantes russos mais antigos; esse, o dos imperadores alemães do antigo Império. O costume russo serviu supostamente à coesão do reino; o costume alemão, que emergiu da falta de uma capital imperial, foi precisamente por isso sinal de uma descentralização preocupante, mas, em tais circunstâncias, todavia o melhor que se pôde fazer em prol da união das diversas partes do Império na pessoa do rei. Preci- 
samente uma das motivações desse viajar em circuito por parte dos soberanos alemães - o fato de que tributos em gêneros tinham que ser consumidos in loco devido à falta de meios de transporte -, precisamente isso estabeleceu uma espécie de relação muito pessoal entre cada distrito e o rei. A um propósito análogo serviu, na Inglaterra, a instalação das Itinerant Justices por Henrique II. Com as deficiências de centralização e comunicação, a administração dos condados por governadores esteve exposta de antemão a abusos consideráveis. Somente os juízes itinerantes levaram a instância estatal superior aonde quer que fosse, somente eles incluíram todas as partes do reino - através da distância que, como estranhos, possuíam em relação a cada uma delas, e através da uniformidade de conteúdo de suas sentenças - na unidade jurídica e administrativa situada para além dos indivíduos, e centralizada no rei. Enquanto ainda faltam os meios supralocais e com efeitos de longa distância, para que também as autoridades local-sedentárias sejam impregnadas de tal unidade, a itinerância dos funcionários oferece a possibilidade mais eficiente de centralizar a dispersão das espacialidades na unidade política idealizada. Justamente em sentido análogo vai também a impressão sensorial acerca de pessoas das quais se sabe que elas vêm daquele ponto central do todo, e que para lá voltarão. Tal imediatismo e visibilidade acarretam uma vantagem para a organização sustentada por elementos móveis, em comparação com aquelas mantidas coesas por meios mais abstratos; vantagem essa que ocasionalmente compensa a maior contingência e isolamento de tal organização. Uma organização inglesa meio socialista, a English Land-Restoration League, utiliza, na sua propaganda entre trabalhadores rurais, carros vermelhos (red vans) nos quais mora o seu orador, e que, seguindo de local em local, formam o respectivo centro das reuniões e agitações. Com toda a sua mobilidade, tal carro não deixa de ser um elemento psicologicamente estacionário, devido à sua aparência característica, conhecida onde quer que seja. Por seu ir e vir ele traz de modo mais intenso à consciência dos partidários dispersos o seu estar-unido através do espaço, do que talvez o fizesse, em condições de resto iguais, uma filial fixa de partido - de modo que outros partidos já devem estar imitando essa propaganda de carro. Ao lado das unidades estatal e partidária, o princípio itinerante também pode servir àquela de cunho religioso. Apenas tardiamente os cristãos ingleses começaram a fundar igrejas paroquiais. Ao menos até bem avançado o século VII, bispos percorreram com seus auxiliares por toda a diocese, a fim de executar os atos eclesiásticos. E, por mais certeza que se tenha de que, pela construção de igrejas, a unidade religiosa de cada comuna individual tenha ganhado uma solidez e visibilidade incomparáveis, isso pôde, contudo, operar mais no sentido de um fechamento particularista da comunidade; já a unidade do conjunto diocesano - e mais: da igreja em geral - deve ter vindo à consciência de modo muito mais intenso pela itinerância de seus representantes. Ainda agora os batistas na América do Norte praticam a propaganda em prol de novos seguidores nas regiões mais remotas por meio de carros especiais, gospel cars, que estariam equipados como capelas. Essa mobilização do culto deve ser 
especialmente favorável à propaganda, por tornar visível aos seguidores dispersos que eles não se encontram em postos isolados, perdidos, mas que pertencem a um todo unificado, mantido coeso por ligações que funcionam incessantemente. E, por fim, é ainda o comportamento ético do grupo em relação a seus elementos itinerantes que, ocasionalmente, deve fazer desses mesmos elementos pontos de encontro e unificação. Devido ao fato de que, na Idade Média, a indispensabilidade da itinerância, para todas as transações econômicas e espirituais, se combinava com seus perigos e suas dificuldades - além do fato de que os pobres, que de todo modo eram objetos da caridade geral, se deslocavam quase constantemente -, podia acontecer que a Igreja recomendasse às orações diárias dos devotos os andarilhos, de um só fôlego com os doentes e presos. $\mathrm{E}$, de modo semelhante, ordena o Alcorão: a quinta parte da presa pertencerá a Deus e seus enviados, e aos órfãos e aos mendigos e aos andarilhos. A caridade direta ao andarilho diferenciou-se mais tarde, em conformidade com uma norma geral de desenvolvimento histórico, na facilitação objetiva do andar por caminhos, proteções, instituições de diversas espécies, e no depender-de-si-próprio e do estar-relegado-às-próprias-forças dos indivíduos, ambos de cunho subjetivo. Aquela obrigação religiosa geral em relação ao andarilho foi o reflexo ético da interação sociológica e da unidade funcional constantes que os andarilhos geravam.

Ao lado desse efeito unificador da itinerância sobre o grupo fixado, que procura superar funcionalmente a sua dispersão espacial pelo ir e vir de elementos individuais, há um outro, que justamente serve às forças antagônicas do grupo. Esse resulta de quando parte de um grupo é, em princípio, sedentária, definindo-se uma outra por sua mobilidade, e quando essa diferença do comportamento espacial formal se torna, então, suporte, instrumento, fator intensificador de um antagonismo latente ou explícito de resto já vigente. Os tipos mais marcantes aqui são o vagabundo e o aventureiro, cuja vagueação contínua projeta sobre o espaço a inquietude, o caráter de rubato de sua rítmica vital interna. A diferença entre os temperamentos de constituição originariamente sedentária e aqueles vagantes já oferece, por si só, possibilidades infinitas de variação para a construção e o desenvolvimento das sociedades. Cada uma das duas naturezas sente na outra o seu inimigo natural e irreconciliável. Porque lá onde não sucede proporcionar ao vagabundo inato, por exemplo através de uma diferenciação fina das profissões, uma atividade adequada a sua constituição - o que muito raras vezes se consegue, visto que já a afinal indispensável regularidade do tempo possui uma afinidade mais do que íntima com a fixação no espaço -, ali o vagabundo existirá como parasita dos elementos sedentários da sociedade. Estes, entretanto, não somente perseguem o vagabundo por odiá-lo, mas o odeiam por terem de persegui-lo em prol de sua autopreservação. E justamente aquilo que coloca o vagabundo nessa posição exposta e atacada - o seu impulso em prol da mudança constante de lugar, a capacidade e o prazer de "fazer-se-invisível" - é, contudo, simultaneamente a sua proteção contra aquelas perseguições e proscrições; é simultaneamente a sua arma de ataque e de defesa. 
Do mesmo modo como a sua relação com o espaço é a expressão adequada de sua interioridade subjetiva e das oscilações desta, ela é expressão das relações dele com o seu grupo social.

Trata-se, aqui, exclusivamente de elementos singulares que, por seu desassossego e sua mobilidade, são forçados mas também capacitados a travar a luta, na verdade, contra a sociedade inteira. Ao menos, são muito raras as associações entre temperamentos vagabundos, em comparação com o entrelaçamento do todo social com esses mesmos temperamentos. À diferença sociológica em relação aos nômades, não se trata, portanto, em tais casos, de comunidades itinerantes, mas de comunidades de itinerantes. A totalidade do princípio vital do aventureiro repugna isso, visto que uma organização dificilmente pode evitar alguma espécie de fixação. Ainda assim, há inícios para isso que se poderia definir como sociações fluidas, mas que, visivelmente, sempre só conseguem incluir e regular uma parte reduzida da vida interna e externa de seus membros. O povo andarilho da Idade Média foi uma tal cooperativa apátrida. Esta necessitava de todo o espírito corporativo daquela época, para que essa gente andarilha estabelecesse para si uma espécie de ordenamento interno, que acabou por chegar, afinal, até a instauração da "mestria" e de outras honrarias. Assim, atenuou-se ao menos a severidade formal do contraste em relação à sociedade restante. Ora, isso ocorre de modo ainda mais marcante no caso de outro tipo de deslocamento de lugar como suporte de um antagonismo social: a saber, onde dois subgrupos são colocados em uma oposição mais vívida por tal deslocamento. Aqui, o melhor exemplo é a itinerância dos oficiais de ofícios mecânicos, especialmente na Idade Média. As organizações nas quais as comunidades dos oficiais se apoiavam, em suas reivindicações perante as cidades e os mestres, tinham como pressuposto a itinerância. Ou, contemplado de outro modo: ambos se encontravam em interação indissolúvel. A itinerância nem teria sido tecnicamente possível sem uma instituição que oferecesse ao oficial mecânico recém-chegado um primeiro ponto de apoio; e era inevitável que quem cuidasse disso fossem precisamente os seus companheiros de estamento, que, eles próprios, se viram ou se veriam nessa situação em algum outro lugar. Como eram precisamente as cooperativas de oficiais mecânicos que atraíam para si a mediação de oportunidades de trabalho, o oficial mecânico, na verdade, não era um estranho em parte alguma na Alemanha (e, correspondentemente, nos outros países). Uma rede de transmissão de notícias entre os oficiais mecânicos atuava com relativa rapidez em prol do equilíbrio entre oferta e demanda de trabalho nos diversos pontos. E, assim, foi primeiramente essa utilidade muito tangível que fez com que, a partir da itinerância dos oficiais mecânicos, emergissem agremiações que se expandiram por todo o reino. O efeito da itinerância foi que as corporações dos oficiais mecânicos mantiveram transações recíprocas mais intensas do que as corporações dos mestres, com a imutabilidade de seu local de residência; que se criou entre eles uma unidade de direito e de costume, que viabilizava a cada um ou às divisões menores um respaldo extraordinariamente forte, nas suas lutas por salário, por 
condições de vida, por honra e posição social. A posição de luta do estamento dos oficiais mecânicos não foi reforçada apenas pelo efeito socializante da itinerância de seus elementos, mas muito diretamente por sua mobilidade: é que esta lhes permitiu realizar suspensões no trabalho e boicotes de tal maneira que os mestres nem tinham como lhes fazer frente. Isso, os mestres só conseguiram de maneira notável quando compensaram as desvantagens de seu enraizamento local por meio de alianças que abrangiam a totalidade da região em cogitação para a itinerância dos oficiais. Desse modo, temos notícia de alianças entre cidades e corporações em prol de frentes solidárias contra os oficiais; alianças que costumavam dizer respeito a uma zona geograficamente fechada, que compreendia uma área regular de itinerância para oficiais. Portanto, duas formas distintas rivalizaram, assim, entre si na luta por dominar um mesmo espaço: à mobilidade por meio da qual o grupo deslocava, para fins de ofensiva ou defensiva, cada um de seus elementos facilmente para lá e para cá - a cada vez até os pontos da menor resistência, e de maior proveito em termos de utilidade -, opunha-se a dominação ideal desse mesmo espaço através dos acordos do outro grupo, distribuído pela área do primeiro. Por meio desses acordos deveriam ser eliminadas as diferenças internas desse grupo, das quais a mobilidade do outro tirava vantagem. Somente depois de estabelecida a uniformidade do comportamento e da força para todos os elementos do grupo dos mestres, a oportunidade advinda da mobilidade do grupo opositor se tornou ilusória. De modo correspondente, o Estado dos séculos XVII e XVIII também conseguiu lidar muito melhor com as corporações dos mestres, que por assim dizer tinham que ficar quietos, do que com as corporações dos oficiais, já que estes tinham como se evadir de qualquer território e impedir o afluxo a ele, podendo assim, portanto, causar graves danos às oficinas. Por isso, também os Estados só conseguiram fazer algo contra as corporações dos oficiais quando, no século XVIII, se procedeu contra eles ao mesmo tempo em uma grande parte do território imperial.

O caráter das sociações é definido formalmente, em grande medida, pela frequência com que seus membros se reúnem. Entre os mestres e os oficiais de ofícios mecânicos, essa categoria se distribui de um modo tão peculiar que, devido a sua sedentariedade, uns com efeito se encontram com frequência e, em geral, tanto quanto necessário, mas justamente apenas dentro de um círculo localmente limitado. Já os outros se encontraram de modo menos completo, mais rara e ocasionalmente, porém, em compensação, numa circunscrição ampla, que inclui muitos distritos de corporações. Assim, enquanto, por exemplo, na Idade Média a quebra de contrato de um oficial era em geral duramente punida, os oficiais tecelões de Berlim obtiveram em 1331 a concessão de que qualquer um podia exigir pagamento e demissão imediatos, quando pensava em sair da cidade. Constitui um exemplo do contexto oposto o fato de que a frequente itinerância e vagueação dos trabalhadores sempre impedem parte deles de participar de um movimento salarial, colocando-os, assim, em desvantagem perante os empresários sedentários. No caso das categorias de trabalhadores já mobilizadas 
em conformidade com a profissão - como trabalhadores rurais migrantes e marinheiros -, a desvantagem da instabilidade se eleva frequentemente até a privação de direitos: em processos de indenização contra o empresário, por exemplo, eles não conseguem de forma alguma ajuntar suas testemunhas e mantê-las juntas durante o moroso processo. Parece, em geral, que quanto maior a proximidade em relação aos dias de hoje, tanto mais favorável é a posição do sedentário, perante o adversário que depende de movimento. E isso se compreende pela facilitação da mudança de lugar. É que esta faz com que também a pessoa em princípio sedentária não deixe, por isso, de poder se mover a qualquer lugar em qualquer momento. Desse modo, para além de sua sedentariedade, ela acaba por gozar mais e mais de todas as vantagens da mobilidade, enquanto à pessoa instável, móvel por princípio, não lhe advieram em igual medida as vantagens da sedentariedade.

Notas

1 Artigo publicado na nova série do célebre Jahrbuch für Gesetzgebung, Verwaltung und Volkswirtschaft im Deutschen Reich (ano 27, v.1, 1903, p.27-71), editado pelo historiador econômico Gustav Schmoller (1838-1917) em Leipzig desde 1875. A Organizadora do dossiê "O espaço na vida social" agradece a Leopoldo Waizbort o incentivo ao projeto de publicação deste texto e as sugestões bibliográficas cruciais. Agradece também a Ingrid Wehr, que viabilizou o acesso ao original de 1903, e a Rainer Domschke o amparo irrestrito no trabalho de tradução.

2 Cf. Georg Simmel, "Das Problem der Sociologie”, Jabrbuch für Gesetzgebung, Verwaltung und Volkswirtschaft im Deutschen Reich, nova série, ano 18, v.4, 1894, p.1301-7. O capítulo futuro a que o autor se refere foi publicado em 1908 sob o título de "Der Raum und die räumlichen Ordnungen der Gesellschaft" [O espaço e os ordenamentos espaciais da sociedade], versão revista e ampliada do texto aqui em questão e que constitui o capítulo 9 da chamada "grande Sociologia" de Simmel, Soziologie. Untersuchungen über die Formen der Vergesellschaftung [Sociologia. Investigações sobre as Formas da Sociação]. Cf. a respeito Otthein Rammstedt (org.), Georg Simmel-Gesamtausgabe, v.2, Frankfurt am Main: Suhrkamp, 1992, p.687-790. (N.O.)

3 No original, “Gestaltungen”. (N.T.)

4 No original, “Moment", termo que em alemão compreende, além do "momento" temporal comum também em português, a acepção de "circunstância decisiva, aspecto", e, no âmbito da física, aquela de produto de duas grandezas, em particular de forças. Dado o conteúdo em jogo neste texto, optamos por um sinônimo à segunda acepção: portanto, por "fator". (N.T.)

5 Cf. de Immanuel Kant, entre outros, Über die Form und die Prinzipien der Sinnenund Geisteswelt [De mundi sensibilis atque intelligibilis forma et principiis, 1770]". Hamburg: F. Meiner, 1958. (N.O.)

6 No original, "Vergesellschaftung”. A opção pela acepção pouco comum em português "sociação" visa ressaltar o caráter processual do termo original, no sentido de "engendrar sociedade (Gesellschaft)" por meio dos efeitos recíprocos dos indivíduos uns em relação aos outros, suas interações. (N.O.) 
7 No original, "im geistigen Sinne"; à falta de um termo mais adequado, traduzimos "geistig” sempre por "espiritual", no sentido amplo de "espírito" ("Geist” em alemão): a opção é referência a todas as capacidades intelectivas e psicomentais dos seres humanos, e não apenas ao sentido mais restrito ligado ao campo religioso e místico, que é como o uso atual tem limitado o campo semântico sobretudo do adjetivo "espiritual”. (N.T.)

8 Tal como formulado, o parágrafo sugere que mais adiante haverá uma parte "II". O texto, contudo, termina sem qualquer alusão a ela. Com efeito, é apenas na publicação do capítulo mencionado na nota 1 que uma segunda parte terá lugar (especialmente às páginas 771-790 do texto em questão). (N.O.)

9 No original, “Gebilde”. (N.T.)

10 No original, "Kommunen", termo historicamente associado às comunidades urbanas da Idade Média alemã. A comuna constitui a menor unidade administrativa, também denominada "Gemeinde", termo comum até hoje e passível, por sua vez, de ser definido como "comunidade" territorialmente definida, abrangendo de aldeias e vilarejos a cidades. (N.T.)

11 No original, "Gemeinde", diferente de "Gemeinschaft", que em português também costuma ser traduzida por "comunidade". (N.T.)

12 Os colchetes indicam trechos que, embora cruciais para a compreensão do conteúdo, estão ausentes do original embora presentes no capítulo mencionado na nota 2 . (N.O.)

13 No original, "Verkehr", termo bastante polissêmico, compreendendo acepções que vão do "trânsito" de veículos ao "intercâmbio" econômico, passando por "transações" e "comunicações" de cunho social dos mais diversos tipos, e abrindo espaço inclusive para a "transa" sexual. Como Simmel emprega a noção em contextos semânticos bastante distintos, optamos pelo sinônimo "transações", no plural. (N.T.)

14 No original, “Atmosphäre des Negers", referência eufêmica ao suposto “odor” do negro. (N.T.)

15 Eis a citação traduzida: "O limite natural de uma democracia é a distância em relação ao ponto central que ainda permite aos cidadãos mais remotos ajuntar-se tão frequentemente quanto as suas funções públicas demandarem". Cf. James Madison, The Federalist No. 14, New York Packet, 30 de novembro de 1787. Disponível em: <http:// constitution.org/fed/federal4.htm>; acesso em 25 ago. 2013. (N.T.)

16 A justaposição desequilibrada dessas duas necessidades, que não encontram uma harmonia, organização, forma complementar em nenhum aspecto superior, que controle ambos, talvez seja a razão para o desenvolvimento parco e difícil das tribos no estágio do nomadismo.

17 David Livingstone (1813-1873) foi um missionário e viajante escocês que se destacou na Inglaterra vitoriana como intrépido explorador do continente africano. Simmel talvez tenha em mente relatos de Livingstone publicados algumas décadas antes por Horace Waller em The Last Journals of David Livingstone, in Central Africa, from 1865 to his Death: Continued by a narrative of his last moments and sufferings, obtained from his faithful servants Chuma and Susi, London: J. Murray, 1874. (N.O.)

18 No original, "auf eine schiefe Ebene geraten”, que Simmel aproveita para um jogo de palavras: trata-se de expressão coloquial para "desviar-se do bom caminho". (N.T.) 
RESUMO - Primeiro ensaio que congrega as reflexões sociológicas de Georg Simmel sobre o papel do espaço na vida social - em particular nos ordenamentos interativos que permitem falar de formas de sociação (Formen der Vergesellschaftung) -, o texto parte de uma concepção específica de espaço, como modo humano de unir estímulos sensoriais desconexos em visões unitárias, a fim de aventurar-se reflexivamente sobre aquelas que seriam as "qualidades fundamentais da forma espacial". Abordadas em cinco seções (anunciadas respectivamente pelas primeiras cinco letras do alfabeto), tais atributos são: a) exclusividade; b) limite; c) fixação; d) relação entre proximidade e distância sensoriais; e) possibilidade de mudança de lugar.

PALAVRAS-CHAVE: Sociologia, Espaço, Interação social, Sociação, Forma.

ABSTRACT - This is Georg Simmel's first essay on the role of space in social life - particularly in the interactive orderings which make it possible to term them forms of sociation (Formen der Vergesellschaftung). Its starting point is a specific concept of space, as a human way of linking sensorial stimuli together into unitary visions. Subsequently the paper reflexively ventures upon the "fundamental qualities of the spatial form", which are tackled in five sections (which in turn are respectively introduced with the aid of the first five letters of the alphabet: a) exclusivity; b) limit; c) fixation; d) the relationship between sensorial proximity and distance; e) the possibility of changing place.

KEYWORDS: Sociology, Space, Social interaction, Sociation, Form.

Georg Simmel (1858-1918), filósofo e sociólogo alemão, foi livre-docente (1885) e professor extraordinário da Universidade de Berlim entre 1901 e 1914, assumindo então a Cátedra de Filosofia na Universidade de Estrasburgo (Alemanha).

Tradução de Rainer Domschke e Fraya Frehse. O original em alemão - "Soziologie des Raumes", publicado em Jahrbuch für Gesetzgebung, Verwaltung und Volkswirtschaft im Deutschen Reich (nova série, ano 27, v.1, Leipzig, 1903, p.27-71) - encontra-se à disposição do leitor no IEA-USP para eventual consulta.

Recebido em 23.9.2013 e aceito em 5.10.2013. 